\title{
Reviewing current knowledge on olive (Olea europaea L.) adventitious root formation
}

\author{
SARA PORFÍRIO ${ }^{1,3 *}$ MARCO D. R. GOMES DA SILVA ${ }^{2}$, MARIA J. CABRITA ${ }^{1}$, \\ PARASTOO AZADI ${ }^{3}$, AUGUSTO PEIXE $^{1 *}$
}

${ }^{1}$ Instituto de Ciências Agrárias e Ambientais Mediterrânicas - ICAAM, Universidade de Évora, 7006-554 Évora, Portugal

${ }^{2}$ LAQV, REQUIMTE, Departamento de Química, Faculdade de Ciências e Tecnologia, Universidade Nova de Lisboa, 2829-516 Caparica, Portugal

${ }^{3}$ Complex Carbohydrate Research Center, The University of Georgia, 315 Riverbend Road, Athens, Georgia 30602, USA

\section{Corresponding authors}

*E-mail: apeixe@uevora.pt

Phone: +351266 760821

Fax: +352266760821

*E-mail: sporfirio@uevora.pt (or porfirio@uga.edu)

Phone: +351 266760821

Fax: +352 266760821 


\section{Abstract}

Olive (Olea europaea) is one of the most important fruit species in the Mediterranean basin, where $95 \%$ of the world's olive orchards are planted, and it has become an economically valuable crop worldwide, due to an increasing interest in olive oil for human consumption. New olive orchards are being planted outside the Mediterranean, calling for an effort to identify the genotypes best adapted to the new conditions. However, some olive cultivars remain difficult to propagate, which significantly reduces the capacity to use the full genetic diversity of the species. Improving rooting ability in cuttings from recalcitrant olive cultivars has become a critical topic, which implies fundamental research on the anatomy, physiology, biochemistry and genetics of the adventitious root formation process. Besides, the existence of different rooting behaviors among olive cultivars also makes the species a candidate model plant for these studies. Olive propagation techniques evolved through time from field- or nursery-planted hardwood cuttings, to semi-hardwood cuttings in greenhouses under mist, and, more recently, to in vitro culture techniques. Nevertheless, research about adventitious root formation carried on each propagation method was mostly based on trial and error approaches. Researchers have mainly investigated different factors involved in the process of adventitious rooting by testing their effect in the rooting capacity of different cultivars, leading to a high dispersion and fragmentation of the available information. The goal of this review is to present the most relevant results achieved on adventitious root formation in olive cuttings, aiming to provide an integrated perspective of the current knowledge.

Keywords: adventitious rooting, auxins, polyamines, propagation, Olea europaea, oxidative enzymes 


\section{General overview}

\subsection{Conceptual basis of adventitious root formation}

Given its simplicity in relation to other techniques, multiplication by cuttings is one of the most relevant vegetative propagation methods, and its success depends on the cuttings' ability to form adventitious roots. While species like chrysanthemum (Chrysanthemum indicum) root easily and display a uniform rooting capacity (Sagee et al., 1992), others, like olive (Olea europaea), show different rooting responses among cultivars (Fouad et al., 1990) and, despite all the research done on the subject, a scientific answer able to explain this contrasting behavior is still unavailable. In fact, most of the current knowledge on adventitious root formation is based on trials developed with model plant species, like Arabidopsis sp. or Tobacco sp. (Kevers et al., 2009; Pijut et al., 2011). In woody perennials, like Olea europaea, the anatomy, biochemical background, genetic control of the process, and the action of exogenous factors able to affect it, remains largely unknown.

Adventitious root formation can occur naturally as part of the normal development of the plant. This happens in most monocotyledonous, where they constitute the main root system (Geiss et al., 2009), as well as in many dicotyledonous, such as strawberries (Fragaria spp.), hops (Humulus lupulus), African violets (Saintpaulia spp.), or blackberries (Rubus spp.) (Bellini et al., 2014), that naturally propagate by vegetative structures. It also represents a plant's response to a stress situation, which can be naturally caused (i.e. environmental stress) or mechanically induced, as a result from wounding following tissue culture or cutting severance (Bellini et al., 2014; Li et al., 2009a).

Two pathways may give rise to adventitious roots: direct organogenesis from established cell types, like the cambium, cortex, pericycle or vascular bundles, which involves cell redifferentiation; and indirect formation from callus tissue, formed upon mechanical damage 
induced by explant preparation. Although the two pathways can occur in the same species, generally, the direct pathway is displayed by easy-to-root species (e.g. Hedera helix), while difficult-to-root ones (e.g. Pinus radiata) are associated with the indirect pathway (Altamura, 1996; Hartmann et al., 1990).

Adventitious rooting was initially considered a one-step process, but, histological and physiological studies (De Klerk et al., 1999; Friedman et al., 1985; Jasik and De Klerk, 1997; Sircar and Chatterjee, 1973), reclassified it as a developmental mechanism, organized in a sequence of interdependent stages, each having its own requirements and features (De Klerk, 1996; Gaspar et al., 1992, 1997; Jarvis, 1986; Kevers et al., 1997b; Rout et al., 2000).

According to Berthon et al. (1990), Heloir et al. (1996), Li et al. (2009a) and Pacurar et al. (2014), three phases can be distinguished; i) induction, corresponding to the period preceding any visible histological event, comprising molecular and biochemical events, ii) initiation, which starts when the first histological events take place, like root primordia organization, and is characterized by the occurrence of small cells with large nuclei and dense cytoplasm, iii) expression, that involves the development of the typical dome shape structures, intra-stem growth and emergence of root primordia.

Such description of the adventitious rooting phases is perfectly adapted to a large number of genuses (e.g. Salix, Populus, Jasminum, Citrus), where preformed adventitious root primordia are present in the stem, but remain dormant until the cuttings are prepared and submitted to conditions favorable to rooting (Altamura, 1996; Blakesley et al., 1991; Geiss et al., 2009; Pacurar et al., 2014). Nevertheless, in cases where these pre-specified cells are not present, an additional dedifferentiation phase exists before induction, where cells reacquire their competence for cell proliferation and organ regeneration (Bellini et al., 2014; Pacurar et al., 2014).

The length of the different phases differs among species (Blakesley et al., 1991; Nag et al., 2001; Naija et al., 2008). In apple (Malus domestica) microcuttings, where no preformed root primordia exist, the dedifferentiation phase occurs during the first $24 \mathrm{~h}$, when cells become competent to 
respond to auxin. De Klerk et al. (1995) showed that after recognizing auxin signals, and until 96h after cutting severance, certain cells become determined to form roots (induction phase). From 96h onwards, these determined cells produce a root primordium from which the adventitious root is developed (differentiation phase). These observations were coincident with histological changes; i) formation of starch grains, during dedifferentiation; ii) first cell divisions and meristem formation, during induction; iii) formation and development of root primordia, during differentiation (De Klerk et al., 1995).

Regulation of the formerly described rooting phases is influenced by a large number of factors, whose interaction remains poorly understood and the underlying molecular mechanisms governing the process remain unknown (Geiss et al., 2009; Legué et al., 2014). Among others, phytohormones (especially auxins and ethylene), polyamines, and oxidative enzymes, are some of the factors that seem to influence and regulate the process of adventitious root formation (reviewed in Li et al., 2009a; Geiss et al., 2009; Pijut et al., 2011).

\subsection{Molecular basis of adventitious root formation}

\subsubsection{Auxins}

Auxins are a class of phytohormones widely used in plant propagation to induce root formation in cuttings (Preece, 2013; Rademacher, 2015). The main endogenous auxin is indole-3-acetic acid (IAA), but there are other natural [indole-3-butyric acid (IBA), 4-chloroindole-3-acetic acid (4Cl-IAA), phenylacetic acid (PAA)] and synthetic compounds [1-naphthaleneacetic acid (NAA), 2,4-dichlorophenoxyacetic acid (2,4-D), 3,6-dichloro-2-methoxybenzoic acid (dicamba), and 4amino-3,5,6-trichloropicolinic acid (picloram)] with auxin activity. IBA was originally chemically synthesized, being only later discovered its endogenous presence in plants (Epstein et al., 1989; Ludwig-Müller and Epstein, 1991), and is, in fact, the second most relevant natural auxin. 
Endogenous IAA is synthesized in meristems and young tissues, such as the shoot apex and young leaves (Ljung et al., 2005; reviewed in Di et al., 2015). From these source tissues, IAA is transported basipetally through the stem to sink tissues. It can move passively in the bulk flow, or be actively transported through the vascular cambium in a polar manner (Teale et al., 2006). This type of polar transport, is gravity independent (Peer and Murphy, 2007) and mediated by carrier proteins (reviewed in Peer et al., 2011). Auxin can enter the cell by diffusion in the protonated form (IAAH) (Ljung, 2013), or through carrier-mediated co-transport, by the action of AUX1/LAX proteins (Blakeslee et al., 2005; Peer et al., 2011). Once inside the cell, because of the neutral cytosolic pH, IAA is in its unprotonated form (IAA $\left.{ }^{-}\right)$and can only exit the cell through efflux carriers - PIN and ABCB proteins (Zažímalová et al., 2010). When applied exogenously, auxins can also be transported acropetally in the xylem (Blythe et al., 2007). Both IAA and IBA can be transported directionally in different tissues and evidence suggests that specific active IBA transporters may exist, as many IAA transporters don't transport IBA (reviewed in Strader and Bartel, 2011). Appropriate auxin transport from the site of application to the site of root initiation can influence the effectiveness of the treatment (Blythe et al., 2007) and several studies have demonstrated the importance of auxin transport in adventitious rooting (Pacurar et al., 2014).

As plant hormones, auxins act at very low levels and their cellular concentration must be highly regulated. This can be achieved by regulation of de novo synthesis (Zhao, 2010) or auxin metabolism. Auxin levels can be irreversibly decreased through oxidative degradation (as discussed in Section 2.2.2.), or reversibly by conjugation with sugar moieties (ester conjugates), amino acids, peptides, or proteins (amide conjugates) (Ludwig-Müller, 2011). Conjugation occurs ubiquitously in higher and lower plants. Interestingly the type of conjugates produced differs between plants (Table 1): while amide conjugates prevail over ester conjugates in dicotyledonous, the reverse happens in monocots (Bajguz and Piotrowska, 2009). 
Table 1: Auxin amide conjugates identified by GC/MS, LC/MS and HPLC-FLD.

\begin{tabular}{|c|c|c|}
\hline Conjugate & Species & Reference \\
\hline \multirow{7}{*}{ IAA-Asp } & Pea (Pisum sativum) & Nordström et al. (1991) \\
\hline & Transgenic tobacco (Nicotiana tabacum) & Sitbon et al. (1993) \\
\hline & Walnut (Juglans nigra $\mathrm{x}$ Juglans regia) & Gatineau et al. (1997) \\
\hline & Rice (Oryza sativa) & Matsuda et al. (2005) \\
\hline & Cherry $(P$. cerasus $\mathrm{x} P$. canescens $)$ & Štefančič et al. (2007) \\
\hline & Chestnut (Castanea sativa $\times$ Castanea crenata) & Gonçalves et al. (2008) \\
\hline & Helleborus niger & Pěnčík et al. (2009) \\
\hline \multirow{3}{*}{ IAA-Glu } & Transgenic tobacco (Nicotiana tabacum) & Sitbon et al. (1993) \\
\hline & Rice (Oryza sativa) & Matsuda et al. (2005) \\
\hline & Helleborus niger & Pěnčík et al. (2009) \\
\hline \multirow{2}{*}{ IAA-Ala } & Arabidopsis thaliana & Kowalczyk and Sandberg (2001) \\
\hline & Helleborus niger & Pěnčík et al. (2009) \\
\hline \multirow{2}{*}{ IAA-Leu } & Arabidopsis thaliana & Kowalczyk and Sandberg (2001) \\
\hline & Helleborus niger & Pěnčík et al. (2009) \\
\hline IAA-Gly & Helleborus niger & Pěnčík et al. (2009) \\
\hline IAA-Phe & Helleborus niger & Pěnčík et al. (2009) \\
\hline IAA-Val & Helleborus niger & Pěnčík et al. (2009) \\
\hline IAA-Trp & Arabidopsis thaliana & Staswick (2009) \\
\hline
\end{tabular}

Conjugation is one way of maintaining a constant pool of free IAA in tissues where auxin homeostasis has been disturbed. Another way of doing so is through IAA storage in the form of IBA (Korasick et al., 2013). As well as IAA, IBA can also be conjugated with other moieties via amide- or ester-linkages (Bajguz and Piotrowska, 2009; Korasick et al., 2013). IBA conjugates are more easily hydrolyzed and more slowly transported (Bajguz and Piotrowska, 2009), which can influence the amount of free auxin at the base of a cutting. 
IBA can also be shortened into active IAA through a peroxisomal enzymatic process, similar to fatty acid $\beta$-oxidation (Zolman et al., 2000). Several enzyme candidates for IBA $\beta$-oxidation have been identified in Arabidopsis (Strader et al., 2011; Zolman et al., 2007; Zolman et al., 2008) and previous doubt regarding IBA having auxin activity by itself (Woodward and Bartel, 2005; Normanly, 2010) no longer seems to make sense, as some authors are confident that the conversion IBA-IAA is essential to IBA auxin activity (Strader and Bartel, 2011; Korasick et al., 2013).

\subsubsection{Polyamines}

Polyamines are low molecular weight cations, ubiquitous to all living organisms (Cohen, 1998), that act as growth regulators and have been described to interact with plant hormones (Alabadi et al., 1996; Altman, 1989; Tonon et al., 2001), although their classification is still controversial (Rademacher, 2015). Given their role in DNA replication, they have been associated with a large number of developmental processes in plants, including cell division and organogenesis, embryogenesis, floral initiation and development, fruit development, root growth, senescence and abiotic stress (Alcázar et al., 2010; Bais and Ravishankar, 2002; Galston and Sawhney, 1990; Kaur-Sawhney et al., 2003; Martin-Tanguy, 2001; Takahashi and Kakehi, 2010).

The major polyamines in plants are putrescine (Put), spermidine (Spd) and spermine (Spm), and their role in adventitious root formation has been suggested by several authors working with woody species (Phaseolus, Jarvis et al., (1985); Vigna, Friedman et al., (1985); apple, Wang and Faust, (1986); tobacco, Tiburcio et al., (1987, 1989); pear (Pyrus sp.), Baraldi et al., (1995); Prunus avium, Biondi et al., (1990); poplar (Populus tremula x P. tremuloides), Hausman et al., (1995a, 1995b); cork oak (Quercus suber), Neves et al., (2002); hazelnut (Corylus avellana), Cristofori et al., (2010)), including olive (Rugini and Wang, 1986). 


\subsubsection{Oxidative enzymes}

Oxidative enzymes have long been related to adventitious root formation. The first reports on this subject suggested that phenolic compounds stimulated root formation as IAA synergists, possibly through inhibition of IAA-oxidase (IAAox) (Gorter, 1969). Later, a protein complex corresponding to polyphenol oxidase (PPO), POX, and IAAox, was reported to emerge in the early stages of rooting of Phaseolus aureus (Frenkel and Hess, 1974). Treatment of cuttings with a PPO inhibitor promoted root formation in Phaseolus vulgaris and Vigna radiata, and its effect was more pronounced during the initiation phase (Gad and Ben-Efraim, 1988), suggesting that PPO had a main role in the regulation of adventitious root formation. However, in contrast, Upadhyaya et al. (1986) claimed that POX and PPO were not involved in the initiation of roots, but rather in their development. In fact, although the involvement of oxidative enzymes in adventitious rooting is abundantly described in the literature, results are frequently contradictory and thus appear to be species- or cultivar-dependent.

Plant peroxidases (class III POX EC1.11.1.7) are hemic proteins involved in a broad spectrum of physiological processes (for a review see Passardi et al., (2005)), including auxin metabolism (Galston et al., 1953). They catalyze the oxidation of diverse electron donors, including phenolic compounds, as well as auxin (Bandurski et al., 1995; Hiraga et al., 2001), using hydrogen peroxide $\left(\mathrm{H}_{2} \mathrm{O}_{2}\right)$ as oxidative agent (Dawson, 1988). Although under most conditions non-decarboxylative oxidation is the main pathway for IAA degradation in vivo (Normanly J., 2010), enzymatic oxidative decarboxylation of IAA can also occur, being catalyzed by a group of POX isoforms named IAAox (Ljung et al., 2002), a group of enzymes which has been largely associated with adventitious rooting (Bansal and Nanda, 1981; Güneş, 2000) (see Section 2.2.2.).

Polyphenol oxidases are a group of copper-containing oxidative enzymes that catalyze two different reactions: the hydroxylation of monophenols to $o$-diphenols (monophenolase activity (tyrosinase) EC 1.14.18.1) (Espín et al., 1997; Mayer, 2006) and the oxidation of $o$-diphenols to $o$-quinones (diphenolase activity (catechol oxidase) EC 1.10.3.2) (Constabel and Barbehenn, 
2008; Escribano et al., 2002; Mayer, 2006). The quinones produced in this reaction, can further polymerize then react non-enzymatically with other compounds, resulting in the formation of products that are believed to protect damaged tissues against herbivores and pathogens (Hind et al., 1995; Mayer, 2006; Robards et al., 1999). In addition to the mono- and di-phenols mentioned above, PPO are also capable of degrading other phenolic compounds that are structurally more complex, such as anthocyanins and other polyphenols (Jiménez and García-Carmona, 1999). PPO display a wide functional diversity, from protection against environmental stress (Thipyapong et al., 1995) to browning reactions (Ciou et al., 2011; Sciancalepore and Longone, 1984; Spagna et al., 2005; Subramanian et al., 1999; Waliszewski et al., 2009). The involvement of PPO activity in adventitious rooting has also been suggested by several authors (see Section 2.2.2.).

\subsection{Suggested models for adventitious rooting in dicots}

In the past decades, using Arabidopsis as plant model, significant progress has been achieved in understanding the physiological and molecular mechanisms behind primary and lateral root development (Casimiro et al., 2003; Muraro et al., 2013; Petricka et al., 2012; Ubeda-Tomás et al., 2012). In contrast, work on adventitious root formation has been more challenging and despite remarkable progresses already made in monocotyledonous species like rice and maize (Hochholdinger et al., 2004; Hochholdinger and Zimmermann, 2008; Zhi-Guo et al., 2012), the knowledge on the mechanisms controlling the process, is not as advanced in dicotyledonous species. Nevertheless, an initial model of adventitious rooting regulation has been proposed based on studies in Arabidopsis (Della Rovere et al., 2013; Gutierrez et al., 2012; Sorin et al., 2006). According to the model proposed by Della Rovere et al. (2013), PIN1 (proteins associated with auxin efflux) transporters initially divert IAA from the basipetal flow along the vascular parenchyma cells towards pericycle cells, activating LAX3 (auxin-inducible protein active in auxin cellular uptake) and promoting subsequent auxin accumulation. PIN1 and LAX3 retain IAA in the recently formed inner and outer layers of the adventitious root and WOX5 (auxin-induced 
protein associated with the positioning of the quiescent center (QC)) is expressed. At this point cytokinin downregulates PIN1 and LAX3 in the periphery and base of the newly formed adventitious root primordium, driving the auxin flow towards the primordium tip through the middle cell rows. This results in an apical auxin maximum which is also a result from IAA biosynthesis by YUCCA6 (auxin biosynthesis-related gene). This auxin maximum limits WOX5 expression at the distal tip therefore positioning the QC. Protrusion is possibly favored by LAX3 present in the hypocotyl epidermis, cortex and endodermis around the root primordium. In the mature adventitious root, the auxin maximum maintained by WOX5 expression and YUCCA6derived biosynthesis also incorporates the QC. At the root tip, auxin homeostasis is partially maintained by cytokinin through downregulation of PIN1 and LAX3.

Gutierrez et al. (2012) also propose a model where auxin regulates adventitious root formation through the regulation of jasmonic acid (JA) homeostasis. In this model auxin-induced activation of ARF (Auxin Response Factor) proteins indirectly regulates the rooting-inhibiting COI1 (protein equivalent to auxin regulatory protein $\mathrm{SCF}^{\mathrm{TIR} 1}$ ) pathway.

Although the molecular mechanisms behind adventitious root formation in model species like Arabidopsis are starting to be revealed, it is still unknown whether it will be possible to translate the current knowledge on adventitious root development in herbaceous species to practical use in woody species (Bellini et al., 2014). Recently, Legué et al. (2014) summarized the recent progress made in the identification of transcription factors associated with the regulation of adventitious rooting in woody species, using Populus sp. as model organism. The present work aims to summarize the current knowledge on adventitious root formation in Olea europaea, another woody species and an important Mediterranean crop, focusing on the anatomical events and biochemical control of the process.

\section{Adventitious rooting in olive stems}




\subsection{Stem anatomy and associated histological changes}

Studies on stem comparative anatomy are fundamental to better understand the histological events leading to adventitious root formation. They allow; i) to identify cells/tissues giving rise to adventitious roots, and which are the target for auxin and other inducing factors; ii) to determine the presence or absence of pre-formed root primordia; iii) to establish a relationship between stem anatomical features and rooting capacity; iv) to create a relationship between physiological and biochemical data and the anatomical phases of root formation (Altamura, 1996).

In semi-hardwood olive cuttings, stem cross sections of easy and difficult-to-root cultivars were already compared and no anatomical differences were found between the studied genotypes. A continuous sclerenchyma ring between the phloem and the cortex was observed (Ayoub and Qrunfleh, 2008; Peixe et al., 2007b). This is considered to be a characteristic feature of the Olea genus (Ayoub and Qrunfleh, 2006) and has been previously pointed out as a possible mechanical barrier to root emergence in recalcitrant cultivars (Ciampi and Gellini, 1963; Qrunfleh and Rushdi, 1994; Salama et al., 1987). However, the most recent data on this subject show that such a ring, even with 3-6 cell layers, can't be a restricting factor for rooting as it crumbles during the rooting process, even in cultivars where only callus formation occurs and root formation isn't achieved (Ayoub and Qrunfleh, 2006, 2008).

Altamura (1996) already suggested that this putative relation between the sclerenchyma ring and the adventitious rooting capacity of a species be ruled out as a cause for recalcitrance in two ways; i) cell expansion and proliferation induced by auxin treatments can cause breaks in the sclerenchyma ring; ii) the developing root primordium instead of pushing through the ring, can go around it, turning downward and emerging from the cutting base.

In Grevillea spp., as in olive, cultivars with differing rooting ability also presented stem cuttings that were anatomically similar, with a continuous sclerenchyma ring separating the cortex and the phloem. However, unlike olive, different anatomical changes were observed during rooting of Grevillea cuttings. In the easy-to-root cultivars, cell division was observed only in a localized 
area of vascular tissue, displacing the sclerenchyma fibers, leaving unaffected other regions of these tissues. In contrast, the difficult-to-root cultivars showed rapid cell division in all tissues (except the pith) and total disaggregation of the sclerenchyma ring, yet these events did not result in organization of new cells to form root primordia. Authors suggest that the lower rooting ability of those cultivars might be related to the loss of competence at the cellular level (Krisantini et al., 2006).

Using in vitro microcuttings from the olive cultivar 'Galega vulgar', Macedo et al. (2013), showed that the events corresponding to the induction phase take place in the first $96 \mathrm{~h}$ after auxin treatment, when cells regain meristematic features. From 96h until 336h, the first meristemoids and morphogenetic root zones were observed, events corresponding to the initiation phase. These events are followed by high mitotic activity that eventually leads to the expression phase, which starts at $528 \mathrm{~h}$ after the root-inducing treatment (Figure 1).

Despite some differences in timing, the cytological events observed in olive by Macedo et al. (2013), are in accordance with observations made in other temperate fruit species like Malus pumila 'KSC-3' (Hicks, 1987), Prunus avium x Prunus pseudocerasus (Ranjit et al., 1988), or Castanea sativa (Gonçalves et al., 1998). Timing differences were expected as the time required for root initiation varies among species from two to eight days (Auderset et al., 1994; Bressan et al., 1982; Gonçalves et al., 1998; Harbage et al., 1993; Ranjit et al., 1988; Samartin et al., 1986; San-José et al., 1992). 


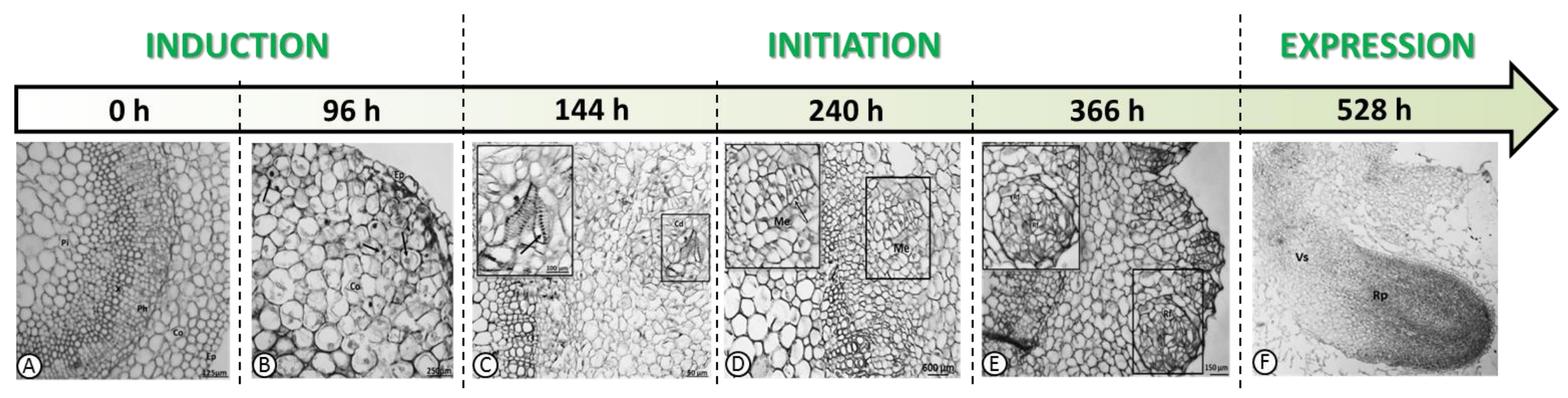

Figure 1 - Histological events happening during adventitious root formation in olive cuttings after root-inductive treatment with $14.7 \mathrm{mM}$ IBA (adapted from Macedo et al. (2013)). (A) Anatomical structure of the stem before IBA treatment, showing a vascular bundle (Pi, pith; Co, cortex; Ep, epidermis; Ph, phloem; X, xylem); (B) Cells in the cortex re-acquire meristematic features, with dense cytoplasm, large nuclei, and visible nucleoli (arrows) (Ep, epidermis; Co, cortex); (C) First cell divisions (Cd) leading to callus formation; (D) Stem section showing two meristemoid structures (Me) in the upper phloem; (E) Morphogenic root zones (Rf) developing from subepidermal cells; (F) Root primordium (Rp), root cap (Rc) and differentiated vascular system (Vs). Magnifications of the circled areas are shown in figures insets. 
Studies performed in apple (Hicks, 1987; Naija et al., 2008; Zhou et al., 1992), chestnut (Gonçalves et al., 1998; Vieitez et al., 1981), oak (Quercus robur) (San-José et al., 1992), Rosa multiflora (Collet, 1985), camellia (Camellia japonica) (Samartin et al., 1986) or artichoke (Cynara scolymus) (Dridi, 2003), all describe similar changes in the stem tissues, with the appearance of larger nuclei (nucleus swelling) and dense cytoplasm in cambial cells and adjacent phloem being the first histological sign of adventitious root formation (Naija et al., 2008). The following step is the occurrence of cell division in or near the cambium zone. In the apple rootstocks MM 106, first cell divisions took place in the phloem region near the cambium (Naija et al., 2008). In other species adventitious roots originate near the vascular cambium (Ahkami et al., 2009, 2013; Hicks, 1987; Park et al., 2002; Rigal et al., 2012; San-José et al., 1992; Syros et al., 2004). The final stage of root formation involves the development of primordia into organized roots, where root primordia protrude among other tissues and roots emerge from the cutting surface (Naija et al., 2008).

Generally, in woody perennials, the origin site is located close to the central core of vascular tissues (Geiss et al., 2009). However, this generalization may comprise many sites of origin (Blakesley et al., 1991; De Oliveira et al., 2013; Jasik and De Klerk, 1997) as the region of the stem tissues where cells become activated seems to depend in part on physiological gradients of substances entering the shoot from the medium and on the presence of competent cells to respond to stimuli (Naija et al., 2008).

In Olea europaea, most authors have observed adventitious roots arising from the cambial region of the stem [Bakr et al. (1977) on cultivar 'Wetaken', Salama et al. (1987) on 'Manzanillo', 'Mission', 'Kalamata', or 'Hamed' and Ayoub and Qrunfleh (2006) on 'Nabali' and 'Raseei']. Studies recently published by Macedo et al. (2013) showed that in cuttings of the easy-to-root cv. 'Cobrançosa' the first morphogenic root fields were also found to be formed in cambial cells, 
confirming previously acquired data. Nevertheless, the same authors reported, in the case of the difficult-to-root cv. 'Galega vulgar', that morphogenic fields were always found in cells from the callus tissue around the base of the cutting. This is in accordance with Therios (2009), who stated that callus formation is a prerequisite for adventitious root formation but, depending on the species, that callus formation may be independent of rooting.

This emphasizes once again the diversity of rooting behaviors among olive cultivars, confirming Olea europaea as a candidate model plant to study adventitious rooting. As stated by Blakesley et al. (1991), rooting differences occurring within the same species arguably provide a better system for investigation as this system removes the chance of genetic causes on evaluation of results.

Table 2 - Rooting capacity of the most commonly cultivated olive cultivars (from Fabbri et al., 2004)

\begin{tabular}{|c|c|c|}
\hline \multicolumn{3}{|c|}{ Cultivar (country) } \\
\hline High $(100-66 \%)$ & Medium $(66-33 \%)$ & Low $(33-0 \%)$ \\
\hline "Easy-to-root" & "Average Rooting" & "Difficult-to-root" \\
\hline Aglandau (France) & Aggezi Shami (Egypt) & Azéradj (Algeria) \\
\hline Arbequina (Spain) & Azapa (Chile) & Bella di Spagna (Italy) \\
\hline Ascolana tenera (Italy) & Bardhe i Tirane (Albania) & Bianchera (Italy) \\
\hline Barnea (Israel) & Bella di Cerignola (Italy) & Biancolilla (Italy) \\
\hline Bouteillan (France) & Bical Castelo Branco (Portugal) & Büyük Topak Ulak (Turkey) \\
\hline Coratina (Italy) & Bidh el Hammam (Tunisia) & Carrasquenha (Portugal) \\
\hline Cordovil Castelo Branco (Portugal) & Cailletier (France) & Chemlal (Algeria) \\
\hline Frantoio (Italy) & Çakir (Turkey) & Chemlali de Sfax (Tunisia) \\
\hline Gordal de Granada (Spain) & Carrasqueño (Spain) & Domat (Turkey) \\
\hline Leccino (Italy) & Chalkidiki (Greece) & Empeltre (Spain) \\
\hline Lechin de Sevilla (Spain) & Chemchali (Tunisia) & Farga (Spain) \\
\hline Lucques (France) & Erkence (Turkey) & Gordal Sevillana (Spain) \\
\hline Manzanilla de Sevilla (Spain) & Galega Vulgar (Portugal) & Leccio del Corno (Italy) \\
\hline
\end{tabular}




\begin{tabular}{lll}
\hline Mission (USA) & Kalamata (Greece) & Lianolia Kerkyras (Greece) \\
\hline Mixan (Albania) & Picholine (France) & Nabali Baladi (Israel) \\
\hline Moraiolo (Italy) & Picholine Marocaine (Morocco) & Nocellara Etnea (Italy) \\
\hline Nocellara Messinese (Italy) & Picual (Spain) & Ogliarola Messinese (Italy) \\
\hline Oblica (Croatia) & Sigoise (Algeria) & Oueslati (Tunisia) \\
\hline Pendolino (Italy) & Taggiasca (Italy) & Salonenque (France) \\
\hline Verdal (Spain) & Verdale de L’hérault (Spain) & Verdeal Alentejana (Portugal) \\
\hline
\end{tabular}

\subsection{The biochemical regulatory network}

In Section 1 the biological function of the major molecules involved in adventitious rooting has been described. Herein the interaction between these factors and how they participate in a complex regulatory network, which culminates in adventitious root formation, will be discussed.

\subsubsection{Role of plant growth regulators}

Auxins play a major role in the control of root development and the current knowledge on this subject is far more developed than it is in adventitious rooting (reviewed in Overvoorde et al., 2010). Nevertheless, the involvement of auxins in adventitious root formation has been proven by several authors (Bellamine et al., 1998; Cooper, 1935; Haissig and Davis, 1994; Zeev Wiesman et al., 1989). Evidence suggests that IAA potentially promotes adventitious rooting through a signaling network similar to that in lateral roots. This network involves auxin response factors (ARF) that regulate the synthesis of auxin-inducible genes (GH3) by modulating jasmonic acid (JA) homeostasis (Gutierrez et al., 2009, 2012). Several lines of evidence show that auxin can stimulate the production of ethylene (Abel et al., 1995; Peck and Kende, 1995; Wilmowicz et al., 2013; Yun et al., 2009), which in turn may promote adventitious rooting (Pan et al., 2002). However, the precise mechanism of auxin action remains poorly understood (Pop et al., 2011). 
Auxin and ethylene regulate each other's metabolism (Robles et al., 2013), in a cross-talk that was also proposed to have a putative regulatory role on adventitious root development. In Arabidopsis hypocotyls, an increased number of adventitious roots was obtained after treatment with ethylene precursor ACC (1-aminocyclopropane-1-carboxylic acid) or in ethylene overproducing mutants (etol), which also display reduced auxin transport. On the other hand, ethylene insensitive mutants (ein2-5 and etrl-1) with enhanced auxin transport showed an increased number of roots. Taken together, these results indicate a negative regulatory role of ethylene on auxin transport and accumulation (by modulating levels of ABCB19 carrier proteins) and ultimately adventitious rooting (Sukumar, 2010). Contradictory results, however, were found in flooded tomato plants, where ethylene stimulated auxin transport through a positive feedback loop (Vidoz et al., 2010). Ethylene also stimulated IAA biosynthesis in roots of Arabidopsis (Růzicka et al., 2007; Swarup et al., 2007). Therefore, the role of ethylene in the regulation of adventitious root formation is still unclear as results differ greatly form species to species. Ethylene can promote adventitious rooting in many species (De Klerk et al., 1999; Druege et al., 2014; Negi et al., 2010; Vidoz et al., 2010), inhibit the process in others (Nordström and Eliasson, 1984; Sukumar, 2010), or even have no effect at all (Batten and Mullins, 1978). Conversely, auxin treatments induce the production of ACC and ethylene, resulting in enhanced adventitious rooting (Riov and Yang, 1989; Visser et al., 1996).

Even though it is assumed that ethylene, unlike auxin, stimulates root expression (Druege et al., 2014), a current hypothesis suggests that ethylene acts indirectly by stimulating auxin biosynthesis and transport to the elongation zone, consequently inhibiting root elongation (Muday et al., 2012; Rahman et al., 2001; Růzicka et al., 2007; Stepanova et al., 2005, 2007). Moreover, unlike auxin-related genes which show a phase-specific pattern, the expression of ethylene-related genes indicates that ethylene is important to stimulate adventitious rooting but not to regulate the process (Druege et al., 2014).

A model of the hormone interactions involved in the different phases of adventitious root formation is proposed by Da Costa et al. (2013) and a more specific model of the regulation of 
adventitious rooting by auxin and ethylene is suggested by Druege et al. (2014). This information was compiled with the model of auxin flow, gene expression and cytokinin localization during adventitious rooting proposed by Della Rovere et al. (2013) (see Section 1.3.) and is presented in Figure 2.

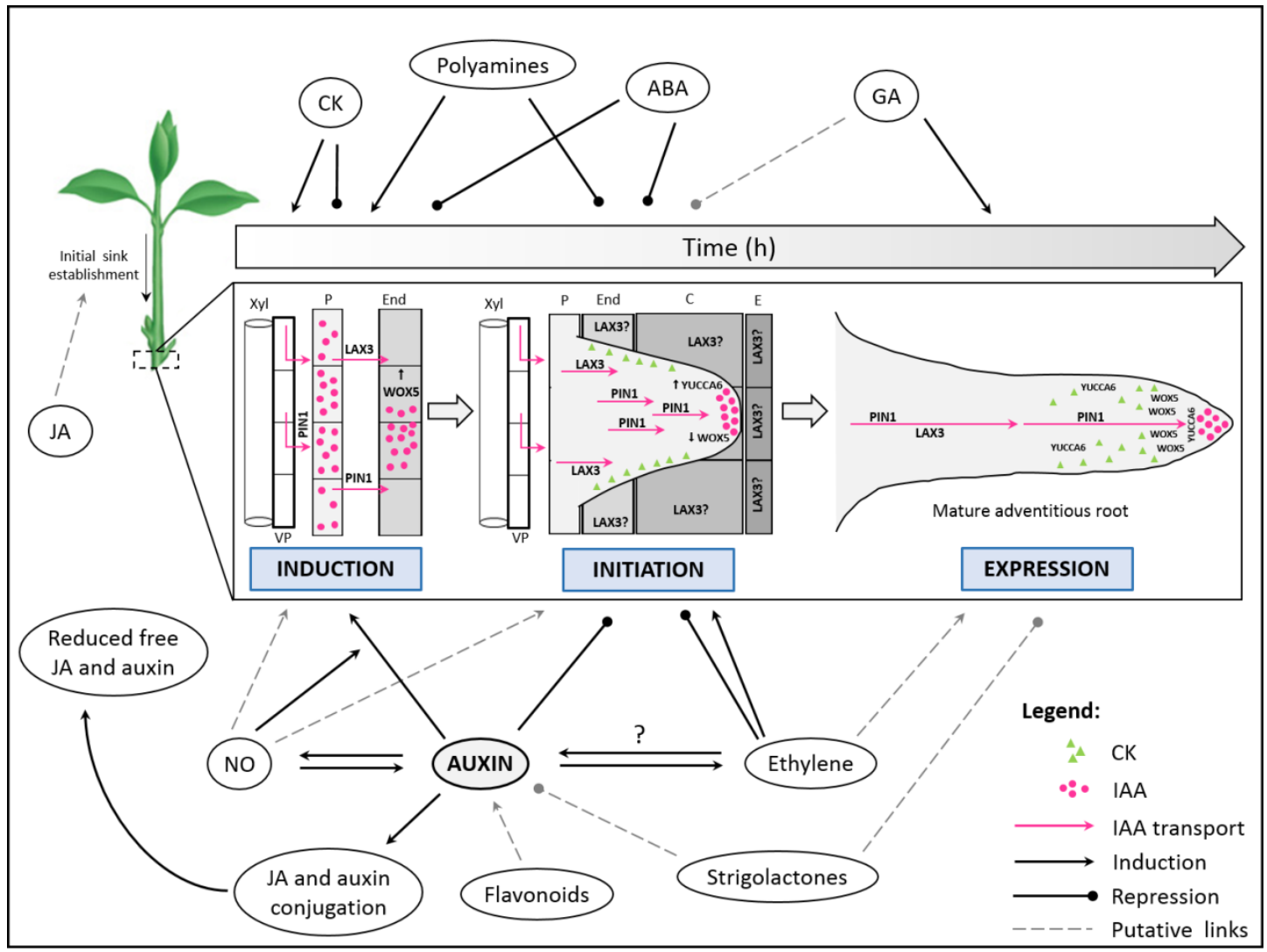

Figure 2 - Possible histological and physiological events and hormone interactions involved in adventitious root formation (adapted from Da Costa et al., (2013), Della Rovere et al., (2013) and Druege et al., (2014)). Initially, JA may promote carbohydrate sink establishment before induction. During induction phase, auxin (IAA) is diverted from the basipetal flow in the xylem by PIN1 transporters, through the pericycle activating LAX3 proteins, and accumulates in the endodermis, increasing the expression of WOX5. This phase is positively regulated by auxin, polyamines, CK and ethylene. CK and ethylene seem to have a dual role, by also negatively regulating induction. ABA inhibits this stage. Levels of JA and auxin are decreased by conjugation with aminoacids, allowing the progress of initiation phase. Strigolactones may suppress auxin action or may directly inhibit adventitious rooting. On the contrary, NO is considered to stimulate both induction and initiation phases. During initiation, PIN1 transporters drive the auxin flow towards the root primordium tip through the middle cell rows because CK down-regulates PIN1 and LAX3 in the peripheral cell layers. This results in an auxin maximum at the distal tip of the adventitious root primordium (ARP), decreasing WOX5 expression and establishing the quiescent center (QC). This auxin maximum is maintained through increased auxin biosynthesis by YUCCA6. Protrusion is possibly favored by active LAX3 in the endodermis, cortex and epidermis around the ARP tip. Initiation phase is negatively regulated by polyamines, auxin, ABA and possibly GA and strigolactones. During expression phase the QC is incorporated in the auxin maximum where WOX5 and YUCCA6 expression are maintained, creating a constant apical auxin 
accumulation. CK is also present in the ARP and contributes to auxin homeostasis by down-regulating PIN1 and LAX3. Ethylene and GA stimulate expression, while ABA acts as a repressor. Xyl, xylem; P, vascular parenchyma; P, pericycle; End, endodermis; C, cortex; E, epidermis; JA, jasmonic acid; CK, cytokinin; ABA, abscisic acid; GA, gibberellin; NO, nitric oxide; aa, aminoacids.

Although the genotype appears to have a stronger influence, changes in auxin concentration have been associated both with the interdependent phases of the process and with the rooting capacity of a species or cultivar (Ayoub and Qrunfleh, 2008; Heloir et al., 1996; Krisantini et al., 2006; Nag et al., 2001; Sagee et al., 1992). According to De Klerk et al. (1995), the high auxin levels needed for the success of induction phase become inhibitory during root expression, meaning that IAA catabolism is mandatory to avoid the inhibition of root development, since high auxin concentrations inhibit root elongation and promote cellular differentiation (Li et al., 2009a). Indeed, auxin influx carrier genes are downregulated during induction phase (Druege et al., 2014) and, for woody species in particular, the development of functional roots throughout the acclimatization of induced microcuttings demands an auxin-free culture medium (Kevers et al., 2009). This way, IAA levels could be used utilized as a marker for the stages of adventitious rooting or to distinguish recalcitrant genotypes from non-recalcitrant.

When auxin reaches the base of a cutting, it could be expected to accumulate in those tissues, even if only transiently. Therefore, differences in auxin transport and accumulation in cuttings could explain the different rooting capacity of easy- and difficult-to-root plants. For example, while easy-to-root cuttings of flametip (Leucadendron discolor) transported more ${ }^{3} \mathrm{H}-\mathrm{IBA}$ to the leaves, more free IBA was accumulated at the base of difficult-to-root cuttings (Epstein and Ackerman, 1993). However, many possible scenarios could explain the behavior of difficult-toroot cuttings: they may metabolize IAA faster than easy-to-root cuttings, leading to lower basal free IAA levels, or the rate of basipetal IAA transport may be lower in this case; there may be a higher concentration of rooting inhibitors at the base of these cuttings; the cells that give rise to root primordia could be less sensitive to auxin or less competent for re-differentiation (Ford et al., 2001). 
Differences between easy- and difficult-to-root genotypes have been associated with their capacity to inactivate auxins through conjugation, as suggested by Epstein et al. (1993) working with Prunus avium, where rooting of a difficult-to-root cultivar was enhanced by inhibitors of IBA conjugation. Authors also reported that IBA conjugation was faster in the difficult-to-root cultivar, suggesting that recalcitrant cultivars may lack the capability of hydrolyzing IBA conjugates during adventitious root formation. Actually, different cultivars of the same species may differ in endogenous amounts of IBA (Ludwig-Müller, 2000).

In olive, to the best of our knowledge, no auxin conjugates have been identified so far. In fact, there is no research done in this area using olive cultivars and there are very few reports of quantification of free auxin levels. Contradicting results found in other species (Krisantini et al., 2006; Sagee et al., 1992), in olive, free IAA levels were found to be higher in the difficult-to-root cv. 'Nabali' than in the easy-to-root cv. 'Raseei' (Ayoub and Qrunfleh, 2008). It is, however, worth mentioning that in this study the levels of growth regulators were measured in buds and leaves and not in the base of the cuttings where root formation occurs.

Differences in IBA-IAA conversion could also explain differences in rooting ability. This conversion was reported in cuttings of Pinus sylvestris (Dunberg et al., 1981), Malus pumila (Alvarez et al., 1989), Populus tremula (Merckelbach et al., 1991), Pyrus communis (Baraldi et al., 1995), Vigna radicata (Chang and Chan, 1976) and Persea americana (García-Gómez et al., 1994). In IBA-treated avocado microcuttings a 2 -fold increase in free IAA levels was observed when compared to control cuttings, as well as an increase in IAA-Asp levels before differentiation (García-Gómez et al., 1994). Some authors also have suggested that IBA treatment can increase the internal free IBA concentration or synergistically modify the action or synthesis of endogenous IAA (Van der Krieken et al., 1993).

IBA-IAA conversion has been described in olive by Epstein and Lavee (1984). After treating 'Kalamata' (difficult-to-root) and 'Koroneiki' (easy-to-root) cuttings with radioactive IBA- ${ }^{14} \mathrm{C}$, most of the recovered radioactivity was found in the form of IAA- ${ }^{14} \mathrm{C}$ at the base of the cuttings, 
and higher conversion rates were found in 'Koroneiki' cuttings. Interestingly, the process was faster in difficult-to-root cultivars (Epstein and Lavee, 1984). This is a very important result considering the inhibitory effect of high auxin levels during initiation phase (De Klerk et al., 1995). If a difficult-to-root cultivar converts IBA into IAA very fast (before and during the induction phase) and doesn't metabolize the resulting free IAA, the initiation phase could be suppressed by the high amounts of auxin and no further root development would be observed. Hence this could explain the recalcitrant behavior of some cultivars. Additionally, exogenous IBA promoted rooting of Arabidopsis stem segments which was inhibited by the auxin polar transport inhibitor 3,4,5-triiodobenzoic acid (TIBA) suggesting a conversion of IBA into IAA (LudwigMüller et al., 2005).

\subsubsection{Role of oxidative enzymes - activity and isoforms}

As previously mentioned (see Section 1.2.3.), IAA levels can also be regulated by irreversible enzymatic degradation through the action of the POX isoform IAAox. Indeed, POX activity is one of the most studied factors involved in adventitious root formation and it has also been suggested as a marker for root formation. In this section the involvement of POX and other oxidative enzymes in adventitious rooting will be described.

So far there is very few information regarding this subject in olive (Olea europaea). Several studies have partially purified, characterized and identified the cellular location of PPO and POX in olive fruits (Ben-Shalom et al., 1977; Lopez-Huertas and Del Rio, 2014; Saraiva et al., 2007; Shomer et al., 1979; Tzika et al., 2009) and both POX and PPO activities have been investigated during unrelated processes such as browning (Goupy et al., 1991; Sciancalepore and Longone, 1984; Segovia-Bravo et al., 2007) and ripening (Ebrahimzadeh et al., 2003; Ortega-García et al., 2008; Ortega-García and Peragón, 2009).

Differences in PPO activity among Vitis rootstocks have been found during rooting (Satisha et al., 2008). Increased PPO activity was observed in response to caffeic acid during rooting of mung 
bean (Batish et al., 2008) and associated with improved rooting in Excoecaria agallocha, Cynometra iripa and Heritiera fomes (Basak et al., 2000). A positive relationship between PPO activity and rooting ability was also found in walnut by Cheniany et al. (2010) and the use of PPO as a marker of the onset and duration of the different phases of rooting was suggested.

Serra et al. (2007) compared the levels of PPO activity in tissues of two olive cultivars with different rooting behavior while trying to establish a relationship between PPO activity and rooting capacity. In both cultivars, higher activity was detected in auxin producing tissues, such as leaves and buds, as described in other species (Szecskó et al., 2004). In agreement with results from eucalyptus (Eucalyptus urophylla) (Li and Huang, 2002) higher activity was found in the easy-to-root 'Cobrançosa' than in the difficult-to-root 'Galega vulgar'. In other species, like the case of Vitis vinifera, however, no relationship was found between PPO activity and rooting capacity (Kose et al., 2011; Yilmaz et al., 2003). The opposite was even observed in Rhododendron sp. where enzyme activity was higher in difficult-to-root cultivars (Foong and Barnes, 1981).

However, it is believed that PPO doesn't influence root formation directly but its effects should rather occur through a disturbance in POX activity, and an inverse relationship between the activities of these two enzymes probably exists (Cheniany et al., 2010). As described above, such a relationship was found in olive by Macedo et al. (2013) while studying the evolution of POX and PPO activities during IBA-induced adventitious root formation of microcuttings of the difficult-to-root 'Galega vulgar'. The inverse trend of POX and PPO activities had been previously described by Qaddoury and Amssa (2003) and by Cheniany et al. (2010) who attributed the decrease in PPO activity to an accumulation of monophenolic compounds, which in turn stimulated POX activity. The results found in olive are in agreement with those described for grapevine (Vitis vinifera, Kose et al., (2011); Yilmaz et al., (2003), Camellia sinensis Rout (2006)) and walnut (Juglans regia, Cheniany et al., (2010). In Vitis vinifera cultivars, a decrease in PPO activity was found to happen at the same time root formation was observed, leading to the conclusion that a decrease in PPO activity is necessary for root formation (Yilmaz et al., 2003). 
The magnitude of changes in PPO activity appears to be larger in easy-to-root cultivars (Cheniany et al., 2010) and, despite some speculation about a relationship between phenolic content and rooting performance (Nag et al., 2001), a clear relation between PPO activity and rooting ability hasn't been found (Rout, 2006; Yilmaz et al., 2003).

POX activity was first associated with rooting capacity by Quoirin et al. (1974) who found higher POX activity in easy-to-root plants, an observation also described by Van Hoof and Gaspar (1976), although it is disputed by some authors (Faivre-Rampant et al., 1998; Foong and Barnes, 1981). Low POX and IAAox activities also favored rooting in Bruguiera parviflora, Thespesia populnea (Basak et al., 2000) and eucalyptus (Eucalyptus urophylla) (Li et al., 2000). Van Hoof and Gaspar (1976) also linked rhizogenesis with a decrease in POX activity and several authors subsequently described an increase in POX activity before root emergence followed by a decrease thereafter (Phaseolus mungo (Bhattacharya and Kumar, 1980); Sequoiadendron giganteum (Berthon et al., 1987), Vitis vinifera (Mato et al., 1988), Populus tremula $\times$ P. tremulö̈des (Hausman, 1993); Casuarina equisetifolia (Rout et al., 1996); Phaseolus radiatus (Pan and Gui, 1997); Prunus dulcis (Caboni et al., 1997); Elaeis guineensis (Rival et al., 1997); Populus nigra, Populus alba and Populus tremula (Güneş, 2000)). IAAox activity was also reported to decrease during rooting of Castanea sativa (Mato and Vieitez, 1986) and Glycine max and this decrease was accompanied by an increase in endogenous levels of IAA (Liu et al., 1996). On the contrary, rooting success in poplar cuttings was attributed to IAA catabolism mediated by an increase in IAAox activity (Güneş, 2000).

The initial reports suggested that a peak of POX activity would mark the end of the induction phase, which was not confirmed by Gaspar et al. (1992) who established that the peak of POX activity determines the end of the initiation phase instead and suggested POX activity as a marker for adventitious root formation. However, its reliability as a biochemical marker can be contested (De Klerk, 1996) in part because in some species the opposite trend was observed: POX activity decreased in the first stages of rooting and increased subsequently [Castanea sativa x C. crenata (Gonçalves et al., 1998); Cucurbita moschata (Xiaoman et al., 1998)]. Unlike the case of most 
auxin-related studies, where Arabidopsis is used as a model organism (Bellini et al., 2014; Della Rovere et al., 2013), research involving POX activity is based in a wide range of species which prevents us from drawing definitive conclusions.

Using microcuttings of the difficult-to-root 'Galega vulgar', Macedo et al. (2013) studied the evolution of POX and PPO activities during IBA-induced adventitious root formation (Figure 3). By comparing the changes in enzymatic activities with histological data authors were able to identify the putative physiological stages of the rooting process in this species for the first time. POX activity decreased to a minimum in the first $96 \mathrm{~h}$ after treatment, which corresponded to the end of the inductive phase, in agreement with findings from Gaspar et al. $(1992,1994)$. POX activity increased subsequently reaching a peak at $336 \mathrm{~h}$. The period between $96 \mathrm{~h}$ and $336 \mathrm{~h}$ could correspond to the initiation phase, as proposed by Gaspar et al. $(1992,1994)$, however in the case of olive a clear relationship between POX activity and root initiation is not observed as it is in other species (Gaspar et al., 1992; Rival et al., 1997; Rout et al., 2000). In the period $336-528 \mathrm{~h}$, which coincided with intense mitotic activity and development of newly formed root meristems, POX activity decreased significantly. The expression phase was observed from $528-720 \mathrm{~h}$, when both POX and PPO activities decreased, in agreement with Gaspar et al. (1992). 


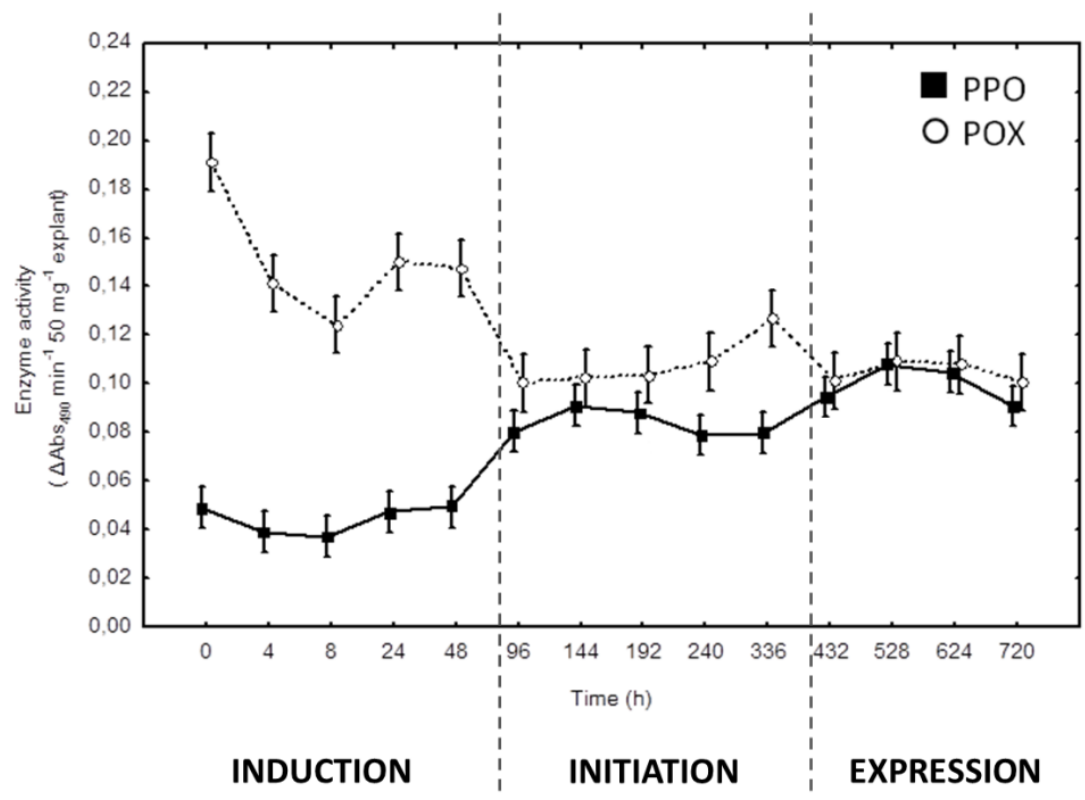

Figure 3 - Changes in peroxidase (POX) and polyphenol oxidase (PPO) activities at different time-points during the development of adventitious roots in in vitro-cultured 'Galega vulgar' olive microshoots. Vertical bars denote \pm standard errors. Rooting phases are highlighted for clarity of presentation (adapted from Macedo et al., (2013)).

The available information on this subject in Olea europaea is still very sparse. The evidence described in the literature regarding other species is extremely inconsistent, and contradictory results can be found among different cultivars of the same species, as the case of Vitis rootstocks (Kose et al., 2011; Satisha et al., 2008). Therefore further studies involving other cultivars are necessary either to confirm or at least clarify the existing results.

The pattern for POX activity found in olive was also found in several other woody species such as grapevine (Vitis vinifera, Yilmaz et al., (2003), Elaeocarpus sylvestris, Gu et al., 2004), walnut (Juglans regia, Cheniany et al., (2010) and mung bean (Vigna radiata, Nag et al., (2001, 2013)). In these species the inductive phase was marked by a minimum of POX activity, followed by a peak that established the end of initiation phase and a subsequent decrease during expression phase. The characteristic peak in POX activity at the end of initiation phase is most likely due to an increase in specific isoforms of POX, as was demonstrated in mung bean where new isoforms were detected at the same time the activity peak was observed (Nag et al., 2013). The isoforms 
involved in this process are probably the so-called IAAox, as the activity of this group of enzymes was inversely related with IAA levels during rooting of Vigna radiata hypocotyls (Nag et al., 2001). An increased expression of POX was also observed in the first $24 \mathrm{~h}$ after cutting severance in Petunia hybrida, which was also associated with IAAox activity (Druege et al., 2014). Interestingly the POX isoform profile (number and relative activity of isoforms) varies throughout the different phases of adventitious rooting (Pastur et al., 2001; Syros et al., 2004) and also differs with rooting ability (Ludwig-Müller, 2003) making it a potential indicator of the underlying processes happening during root formation (Pastur et al., 2001). In olive, Bartolini et al. (2008) reported the emergence of a "new polypeptide" that could be related to root formation. However, the results are not clear, the putative protein was not further purified and the conclusions drawn are merely speculative. On the contrary, in narrow-leafed ash (Fraxinus angustifolia, (Tonon et al., 2001) another species of the Oleaceae family, POX activity increased in the expression phase, as described also in other species like date palm (Phoenix dactylifera, (Qaddoury and Amssa, 2003), Camellia sinensis (Rout, 2006) and apple (rootstock MM106, (Naija et al., 2009)). This is supported by findings of Tartoura et al. (2004) who suggested that POX (IAAox) is only involved in initiation and expression of adventitious roots, as during root induction IAA conjugation is the most likely cause of downregulation of IAA levels. These findings reinforce the need for more studies in olive as they show that changes in POX activity during adventitious root formation may vary within species. So far no data is available regarding POX activity in olive cuttings with different rooting ability. This is definitely an important area of future investigation, as it has been described that the POX activity peak can shift in time when the rooting success rate is low (Rival et al., 1997) and that the POX peak can be higher in easy-to-root cultivars (Cheniany et al., 2010; Kose et al., 2011), therefore establishing a relation between POX and rooting capacity.

\subsubsection{Role of hydrogen peroxide}


Most studies on oxidative enzymes consider that POX affects adventitious root formation through regulation of IAA levels accomplished by IAAox. However, some authors have suggested that POX may act indirectly through $\mathrm{H}_{2} \mathrm{O}_{2}$, given the rooting-stimulatory effect of $\mathrm{H}_{2} \mathrm{O}_{2}$ (Sebastiani et al., 2002; Sebastiani and Tognetti, 2004) and the inhibitory effect of its scavengers (Li et al., 2009b). Li et al. (2009b) reported an increase in endogenous $\mathrm{H}_{2} \mathrm{O}_{2}$ levels in mung bean seedlings after IBA treatment and removal of the primary root, suggesting that IBA may induce rooting indirectly through a pathway involving polyamines and $\mathrm{H}_{2} \mathrm{O}_{2}$. Moreover, treatment of mung bean seedlings with $\mathrm{H}_{2} \mathrm{O}_{2}$ resulted in a decrease of POX activity ( $\mathrm{Li}$ et al., 2009c). In olive, exogenous application of Put induced a POX peak (Özkaya and Celik, 1994; Rugini et al., 1990, 1997) which could be a result of Put degradation through the $\Delta^{\prime}$-pyrroline pathway, where $\mathrm{H}_{2} \mathrm{O}_{2}$ is the main by-product (Tiburcio et al., 1997). $\mathrm{H}_{2} \mathrm{O}_{2}$ accumulation could then stimulate POX activity (Gaspar et al., 1997; Rugini et al., 1992) and ultimately root formation. Furthermore, $\mathrm{H}_{2} \mathrm{O}_{2}$ seems to interact with alternative oxidase (AOX) (Macedo et al., 2009, 2012) and nitric oxide (NO) (Da Costa et al., 2013).

\subsubsection{Role of polyamines - depletion/accumulation}

Treatments with inhibitors of polyamine synthesis, like difluoromethylornithine (DFMO) and $\alpha$ difluoromethylarginine (DFMA), tend to inhibit adventitious rooting (Hausman et al., 1994; Martin-Tanguy and Carré, 1993; Naija et al., 2009) and this effect can be partially reversed by exogenous polyamine treatment (Biondi et al., 1990). Additionally, depletion of polyamine pools has been linked to root growth inhibition (Couée et al., 2004) and polyamine accumulation was related to rooting (Altamura et al., 1991, 1993; Friedman et al., 1982, 1985; Jarvis et al., 1983).

In olive, polyamines (especially Put) have been reported to stimulate rooting in several cultivars. Combined treatments with IBA + Put increased rooting percentage and promoted early rooting of 'Frangivento', 'Pendolino', 'Frantoio', 'Moraiolo', 'Dolce Agogia' and 'Chondrolia Chalkidikis' cuttings, while the stimulatory effect of pure Put was dependent on season (Grigoriadou et al., 
2002; Rugini, 1992; Rugini et al., 1990). Interestingly, the positive effect of polyamines was also observed when rooting was induced by Agrobacterium rhizogenes in the absence of exogenous auxin (Rugini, 1992). The endogenous polyamine content of the cuttings also seems to influence their rooting capacity. Easy-to-root olive cuttings show higher polyamine content and the peak of free polyamine content is coincident with the highest rooting percentage (Denaxa et al., 2014). This supports the role of free polyamines in rooting previously suggested by other authors (FaivreRampant et al., 2000; Neves et al., 2002; Rugini et al., 1993, 1997; Tiburcio et al., 1989). Thus, the recalcitrance of genotypes like 'Kalamata' has been attributed to a low content of free polyamines (Denaxa et al., 2014) and, interestingly, the predominant polyamine found in cuttings appears to be dependent on genotype. For example, in the case of 'Arbequina' and 'Kalamata', even though Spd was found to be the predominant polyamine, Put was the most effective in promoting rooting (Denaxa et al., 2014).

Nevertheless the effect of polyamines in adventitious rooting is still controversial and seems to be dependent on species. Polyamine treatment had little to no effect on cuttings of Malus pumila, Prunus dulcis, Pistacia vera (Rugini, 1992), chestnut, jojoba (Simmondsia chinensis) and apricot (Prunus armeniaca) (Rugini et al., 1993), but it decreased rooting in walnut and increased rooting in apple and olive (Naija et al., 2009; Rugini et al., 1993). Other factors such as basal shoot darkening, type of explant and endogenous level of polyamines also seem to influence the response to polyamine treatments. In fact, the content of total free polyamines in cuttings (which in olive is low) seems to be inversely related with the response to exogenous Put treatments (Rugini et al., 1993). There seems to be a relationship between the endogenous polyamine content and the early stages of rooting (Jarvis et al., 1985; Biondi et al., 1990; Heloir et al., 1996; Neves et al., 2002) and therefore, polyamines have been suggested as markers for adventitious rooting. Much like POX, changes in Put levels have been related to rooting phases: an early peak followed by a decrease was attributed to induction phase (Denaxa et al., 2014; Gaspar et al., 1997; Kevers et al., 1997a) and a second peak marked the expression phase (Denaxa et al., 2014; Nag et al., 
2001). In fact, explants treated with auxin had increased levels of polyamines before root emergence (Desai and Mehta, 1985; Friedman et al., 1982; Geneve and Kester, 1991).

Some authors suggest that polyamines stimulate rooting through an increase in POX activity since treatment with $\mathrm{H}_{2} \mathrm{O}_{2}$ (a product of Put catabolism and POX substrate) increased rooting percentage and promoted early rooting (Rugini et al., 1992). On the other hand, evidence suggests a combined role of polyamines and auxins in the regulation of the early events of adventitious rooting. Put and IAA levels varied in parallel during root induction and initiation of Vigna cuttings (Nag et al., 2001).

\subsection{Factors affecting rooting performance by interfering with the availability of biochemical compounds}

In the previous sections the most crucial factors controlling adventitious rooting were presented. However, their availability can be affected by other numerous endogenous and exogenous factors. For instance, auxins are produced in young leaves and buds (source tissues) and transported to the base of the cutting (sink tissues), therefore, the age of the cutting, as well as the presence of leaves and buds, can affect auxin availability.

Most research aiming to improve rooting of difficult-to-root olive cultivars, is based on the effect of such factors. Studies are not systematic and were mostly performed on trial and error basis. The main results of such studies are compiled in Supplementary Material and briefly discussed below. However, this section doesn't aim to be an exhaustive review on all the endogenous and exogenous factors affecting adventitious rooting in olive, but instead to present the major results achieved with experiments involving factors able to affect the availability of biochemical compounds.

\subsubsection{Cutting size and age}


Several authors have studied the effect the cutting size on rooting as it can affect the amount of available auxins. The results achieved for olive are not consistent, being highly dependent on the cultivars and cutting type (Supplementary Material).

In hardwood cuttings, the increase in cutting size negatively affects rooting being accompanied by a decrease in the number of roots per cutting (Awan et al., 2012). A reverse trend is observed in semi-hardwood cuttings and microcuttings (De Oliveira et al., 2003; Haq et al., 2009). On such propagation materials, rooting tends to improve with increasing cutting size, something that can potentially be attributed to greater carbohydrate reserves, higher amounts of accumulated endogenous auxins, and higher number of competent cells (Haq et al., 2009).

Furthermore, the maturity of the shoot used for cutting preparation seems to strongly affect rooting performance (Therios, 2009). In fact, is now broadly accepted that the origin of the propagation explant in relation to its position on the tree, can, independently of its nature (hardwood, semi-hardwood, or softwood), affect the capacity for adventitious root formation. Explants taken from the juvenile cone of the plant (basal part of the leader trunk) show higher rooting capacity than those taken from the upper part of the tree Porlingis and Therios (1976), which is probably related with the higher cell differentiation of the latter ones.

\subsubsection{Type and concentration of auxin}

The type and concentration of auxin used in root-inducing treatments is one of the most studied topics. When using semi-hardwood cuttings, IBA is the most commonly used auxin as it frequently promotes rooting more efficiently than NAA (Das et al., 2006; İsfendiyaroğlu and Özeker, 2008), with a few exceptions (Serrano et al., 2002). In other cases, however, the combination of both auxins results in better rooting rates, but genotype seems to play a major role (Denaxa et al., 2010; Khabou, 2002). IBA also produces better results than NAA in microcuttings (Bati et al., 1999). Although many concentrations of IBA have been tested (Supplementary Material), there isn't a universal concentration that will induce rooting in all cultivars. Actually, 
different rooting parameters can be improved by different IBA concentrations (Kurd et al., 2010; Pio et al., 2005). Nevertheless, optimal IBA concentrations for semi-hardwood cuttings are in the range $500-6000 \mathrm{ppm}\left(\mathrm{mg} \mathrm{L}^{-1}\right)$ (Supplementary Material) and for microcuttings optimal concentrations of 1.25 and $1.5 \mathrm{mg} \mathrm{L}^{-1}$ have been reported (Ali et al., 2009; Haq et al., 2009).

\subsubsection{Presence of buds and leaves}

Leaves and buds are sites of photosynthesis and auxin production (Ljung et al., 2001) and therefore can potentially influence the rooting performance of cuttings by altering auxin levels and carbohydrate reserves.

In olive, the presence of leaves in the cuttings seems to play a minor role in adventitious root formation for some cultivars (De Oliveira et al., 2003), but an inhibitory effect was described in other cases when leaves and buds are removed (Avidan and Lavee, 1978; Caballero and Nahlawi, 1979; Fontanazza and Rugini, 1977). The presence of leaves has been reported to significantly improve callus and root formation, and to decrease outgrowth of buds to shoots (Suárez et al., 1999). However, auxin treatments still seem to exert a stronger influence on rooting success (Pio et al., 2005).

\subsubsection{Seasonality}

The time of the year when cuttings are taken also seems to influence rooting performance and thus is important to choose the ideal season to get a maximum rooting response. Despite some discordant results (Mousa, 2003; Talaie and Ghassemi, 1996), there is a general seasonal trend for rooting percentage, with a maximum in summer and minimum during autumn and winter (Da Silva et al., 2012; De Oliveira et al., 2003; Fouad et al., 1990; Gellini, 1965; Mancuso, 1998; Therios, 2009; Usta, 1999). Differences in rooting response are attributed to the alternate-bearing behavior displayed by stock plants which in turn can be related to changes in carbohydrates over 
seasons (Denaxa et al., 2012; De Oliveira et al., 2003; Özkaya and Çelik, 1999). The proximity to harvest was also pointed as an explanation for a better rooting response at a certain time of year (De Oliveira et al., 2009). However, juvenility also needs to be taken into account: while juvenile cuttings have optimum rooting performances regardless of season, mature cuttings will root better if collected in late spring and/or summer (Therios, 2009).

The poor rooting response observed in 'Nabali' cuttings was attributed not only to IAA levels per se but also to their seasonal variation. Periods of higher rooting percentages were coincident with higher levels of IAA and ABA and lower levels of rooting inhibitors such as GAs and cytokinins (Ayoub and Qrunfleh, 2008).

Interestingly, in vitro explants carry over this seasonal behavior, which can be postponed by the darkening of the rooting medium (Mencuccini, 2003).

\subsubsection{Light and darkening}

Light and darkening can affect adventitious root formation in several ways. Light intensity, light quality or light exposure time are reported to influence rooting in many species (Fett-Neto et al., 2001; Jarvis and Shaheed, 1987; Sorin et al., 2005), including olive (Morini et al., 1990; Therios, 2009). Low light intensity can increase rooting percentage; long photoperiods can increase carbohydrate accumulation and induce rooting; light color can affect rooting, in a speciesdependent manner (Therios, 2009). In addition, a dark environment at the base of cuttings can enhance the accumulation of photosensitive auxins therefore improving rooting, as observed in many species (Pan and Van Staden, 1998).

In olive, it was found that darkening the bases of in vitro cultured explants enhances rooting response (Rugini et al., 1988, 1993). Initially, darkening was achieved by painting the outside of the vessels black or by placing black sterile polycarbonate granules in the surface of the rooting medium. However, this cumbersome approach was not practical and other alternatives were 
found. Black dye (Mencuccini, 2003) or activated charcoal (Peixe et al., 2007a) are frequently added to the rooting medium. In other cases, a 5 day-long dark pre-treatment before subculture is used (Rugini and Fedeli, 1990; Zacchini and De Agazio, 2004) to improve rooting performance, which indicates an inhibitory effect of light on rooting. In the absence of the dark pre-treatment, no rooting was obtained (Sghir et al., 2005) which could be attributed to a rooting inhibition associated with continuous exposure to auxin-like regulators, as shown for other woody species (Druart, 1997). Furthermore, darkening eliminates the differences in rooting ability observed in vivo among cultivars (Mencuccini, 2003).

\subsubsection{Wounding}

Wounding at the base of the cutting can enhance rooting, particularly when mature stock plants are used, by promoting cell division through auxin and carbohydrate accumulation at the wounding site. It also facilitates the absorption of exogenously applied auxin (Therios, 2009). Studies regarding wounding of semi-hardwood cuttings of olive are not abundant, and the few existing studies are quite contradictory and seem to depend on the cultivar (see Supplementary Material).

While in some cultivars basal cuts improved rooting (Talaie and Malakroodi, 1995), in other cases no differences in rooting response were observed between wounded and unwounded cuttings (Talaie and Ghassemi, 1996). In the case of girdling, results were affected by the type of cutting and growing season (Usta, 1999).

\subsection{Other factors known to affect adventitious rooting}

Much of the available information in the literature refers to the biochemical control of adventitious rooting, although other variables can affect the process, even if indirectly. Research 
in adventitious rooting of olive described other factors which may also influence the final outcome of cutting propagation (see Supplementary Material).

An intact seed in the cutting can prevent rooting through competition for assimilates (Del Rio, 1989). The nutritional status of stock plants is determinant to the rooting capacity of the cuttings produced from them. The type of rooting substrate can greatly affect the success of root formation as a result of specific properties such as substrate porosity, water retention capacity, $\mathrm{pH}$ and level of nutrients (Therios, 2009). In the case of microcuttings, culture media composition is detrimental to the efficiency of in vitro multiplication, as mineral composition of the medium (Cozza et al., 1997; Rugini and Pannelli, 1993), growth regulators (Chaari-Rkhis et al., 1997) and carbon source (Garcia et al., 2002; Leva et al., 1994) can determine the success of a micropropagation protocol. Application of growth retardants in combination with auxin can improve rooting ability, (Davis et al., 1985; Wiesman et al., 1989) possibly through inhibition of gibberellin biosynthesis (Rademacher et al., 1984).

Similarly, fertilizers containing essential nutrients such as boron and zinc can also enhance rooting response (Ali and Jarvis, 1988; Schwambach et al., 2005). Boron has been associated with the maintenance of cell division and cell enlargement (Josten and Kutschera, 1999) and lignin biosynthesis (George and De Klerk, 2008). It also has been suggested as a structural component of primary cell walls (Hu et al., 1996) and to have a role in the control of endogenous auxin levels (Jarvis and Booth, 1981) by promoting IAA destruction and translocation (Goldbach and Amberger, 1986; Jarvis, 1984). Zinc is required for the synthesis of the auxin precursor tryptophan (Trp) (Blazich, 1988; Marschner, 1995), and is also a structural component of auxin receptor ABP1 (Auxin-Binding Protein 1; Tromas et al., (2010)). Manganese and iron are co-factor and structural components of POX, respectively, and can therefore affect rooting rates by modulating this class of enzymes (Campa, 1991; Fang and Kao, 2000). Similarly, the inorganic composition of culture media can affect rooting performance, depending on species, cultivar and growth conditions (Geiss et al., 2009). 
Carbohydrate reserves are the main source of energy to drive the formation of root primordia in cuttings (Calamar and De Klerk, 2002; Li and Leung, 2000) and have been related with rooting ability of cultivars (Aslmoshtaghi and Shahsavar, 2010; Yoo and Kim, 1996). Seasonal variations in carbohydrate levels have been suggested as an explanation for the seasonal rooting ability of olive cuttings (Del Rio et al., 1991). Carbohydrates also modulate gene expression (reviewed in Gibson, 2005) and interact with plant hormone signaling (reviewed in Eveland and Jackson, 2011; Gibson, 2004; León and Sheen, 2003). Daily fluctuations in sugar content have been related with changes in auxin levels (Sairanen et al., 2012) and it has been suggested that sugars affect auxin conjugation and/or transport (Ljung et al., 2015). However, the exact role of carbohydrates in adventitious rooting is still controversial (Ragonezi et al., 2010) and apparently their allocation and distribution within the cutting has a greater influence than the content itself (Druege, 2009; Druege et al., 2000; Ruedell et al., 2013). Nevertheless, the positive effects of exogenous application of carbohydrates on rooting performance are often related with low reserves of the cuttings. Loach and Whalley (1978) obtained a 33\% increase of in vitro rooting percentage of several woody species with the external application of $2 \%(\mathrm{w} / \mathrm{v})$ sucrose, but only when the cuttings were subjected to low levels of light intensity. Likewise, Del Rio et al. (1986) were able to increase considerably the rooting capacity of 'Picual' olive cuttings, by immersing the base of the cuttings in a $15 \%(\mathrm{w} / \mathrm{v})$ sucrose solution, although the rooting increase was only observed in stems containing floral buds.

The effect of other factors, such as electrical impedance and cold storage, has also been studied in different olive cultivars, being the main achieved results summarized in Supplementary Material.

\section{Microbial symbiosis and adventitious rooting in olive}


Although most research is focused on the chemical factors governing adventitious rooting, biological interactions with fungi and bacteria have also been described to enhance root formation and growth. Arbuscular mycorrhizae (AM) are broadly used in micropropagation for improving the performance of the propagated plantlets and reducing the acclimatization time (Kapoor et al., 2008). Inoculation of micropropagated plants with arbuscular mycorrhizal fungi (AMF) results in a highly branched root system, containing adventitious roots with higher diameter (Kapoor et al., 2008). It also increases photosynthetic efficiency, water conducting capacity, protects the plant from soil pathogens and environmental stress (Kapoor et al., 2008), and increases the survival rates of difficult-to-root plants (Azcón-Aguilar and Barea, 1997).Application of ectomycorrhizal fungi to the vegetative (micro)propagation of valuable plant species is a well-known and studied subject in woody plants like conifers (reviewed in Niemi et al., 2004).

Olive is known to form AM (Roldán-Fajardo and Barea, 1985) with obligate plant symbionts of the order Glomales (Calvente et al., 2004). There is a wealth of information concerning the beneficial effects of these symbiotic associations in contexts, such as drought and salinity tolerance (Porras-Soriano et al., 2009; Mekahlia et al., 2013). AM fungi are reported to have a positive effect in the development and survival of micropropagated plants by improving plant establishment, increasing rhizosphere volume, improving nutrient uptake, protecting the plant against biotic and abiotic stress and improving soil structure. Their influence is particularly important during acclimatization of micropropagated plants by reducing the stress of transplantation (Azcón-Aguilar and Barea, 1997; Kapoor et al., 2008; Mechri et al., 2014; Smith and Read, 2010), as described for olive (Meddad-Hamza et al., 2010). However, studies involving the effect of mycorrhizae in adventitious rooting are less common.

Inoculation of olive cultivars with the AM fungus Glomus mosseae resulted in higher survival rates, shoot height and node number (Binet et al., 2007). This eventually resulted in a successful acclimatization and faster development of the economically valuable ecotype 'Laragne', which is able to grow beyond the limit of the Mediterranean climate (Chas, 1994). Thus, AM fungi can be included in micropropagation programs to promote the culture of important olive genotypes. 

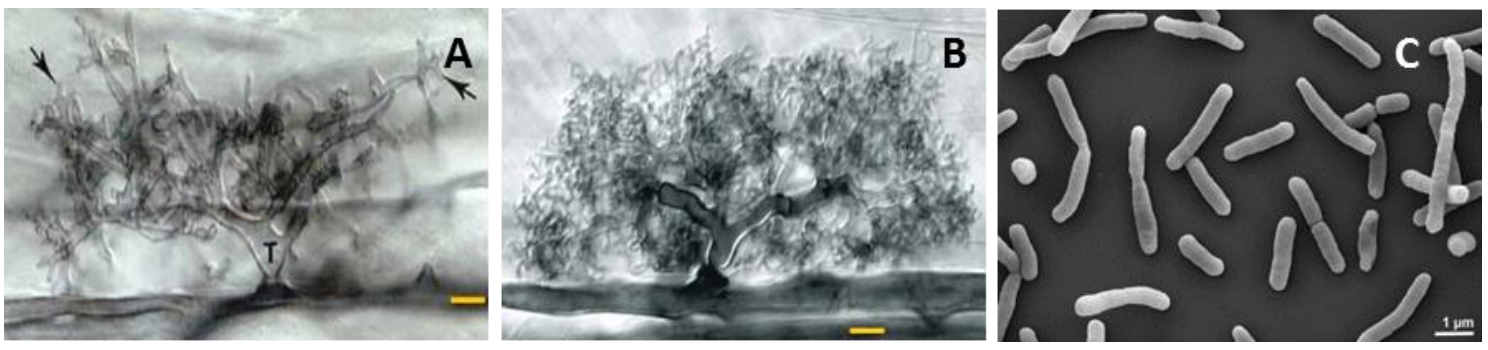

Figure 4 - Microbial associations found in Olea europaea. (A) Developing arbuscule of Glomus mosseae in a root cell; (B) Mature arbuscule of Glomus mosseae with branched hyphae; (A) and (B) Bar $=10 \mu \mathrm{m}$ (from "Arbuscular Mycorrhizas," http://www.sft66.com/fungi/html/vam.html); (C) Scanning electron micrograph showing cells of Chryseobacterium oleae strain CT348T (from Montero-Calasanz et al., 2014).

Inoculation with selected AM fungi has been reported for 'Arbequina', 'Leccino', 'Moraiolo', 'Frantoio', 'Misión', 'Picual' and 'Cornicabra' cultivars. However, as described for other species (Camprubi and Calvet, 1996; Linderman and Davis, 2001), the degree of responsiveness to mycorrhizae was shown to be dependent both on genotype and AM fungi species or strain used for inoculation (Calvente et al., 2004; Citernesi et al., 1998; Estaún et al., 2003; Ganz et al., 2002; Piedra et al., 2003). Moreover, the substrate used for acclimatization of inoculated plants can influence root colonization (Bustos, 2012). AM fungi have even been used in wild olive (Olea europaea ssp. sylvestris) plants, where inoculation not only increased shoot biomass, but also enhanced the activity of antioxidant enzymes as well as other physiological parameters (Alguacil et al., 2003; Caravaca et al., 2003).

Mechri et al. (2014) found that olive tree root colonization with the AM fungi Glomus intraradices induced significant changes in the bacterial community structure of olive tree rhizosphere compared to non-mycorrhizal plants. This mycorrhizal effect on rhizosphere communities may be a consequence of changes in characteristics in the environment close to mycorrhizal roots, granting suitable conditions for other microorganisms and eventual synergic interactions.

Besides AM, a species of plant growth promoting bacteria has been identified in olive. Very recently, Montero-Calasanz et al. (2014) identified a novel species of bacteria, Chryseobacterium 
oleae (type strain CT348T), isolated from the ectorhizosphere of an organically farmed olive tree cv. 'Arbequina'. Among the evaluated bioproducts of the strain, several polyamines were found that are known to be involved in adventitious root formation (discussed in Section 2.2.4.). Symhomospermidine is the major polyamine produced but spermidine and spermine were also determined as minor components. Traces of putrescine and cadaverine were also detected. Chryseobacterium genus members have also been considered an important bacterial group associated with plants (Anderson and Habiger, 2012; Brown et al., 2012; Lee et al., 2006) and are thought to possess plant-growth promoting activities (Dardanelli et al., 2010; Montero-Calasanz et al., 2013).

\section{Conclusions}

Much of the available information on olive adventitious root formation has been published in specific symposia and, frequently, only the abstract of such communications is accessible. This problem, associated with the absence of a continued line of work on the fundamental aspects of adventitious rooting (anatomy, physiology and genetics), has considerably hindered the collection of information presented in this paper.

In woody perennials, the difficulty in establishing analytical methods that allow collecting this type of data has definitely contributed to the lack of fundamental studies on adventitious rooting. In such species, most rooting assays are not systematic and so far have been based on empirical knowledge, where the effect of factors known to affect the formation of adventitious roots is evaluated.

From the gathered information, some conclusions seem however to be consolidated:

- In olive, there is no evidence for the existence of preformed roots. However, the presence of latent meristematic structures in older branches, which can evolve to form new adventitious roots when subjected to suitable conditions, seems to be established. Such structures, together with high levels of nutritional reserves in the cuttings, have clearly 
enabled the use of propagation by hardwood cuttings, a method used in olive propagation since ancient history.

- Differences in the rooting ability of cultivars cannot be explained by anatomical features of the stem. The sclerenchyma ring typically found in Olea europaea is not significantly different among varieties and therefore doesn't explain the observed variability in rooting behaviors.

- Auxin is a limiting factor in the rooting of semi-hardwood cuttings since acceptable rooting rates can't be obtained in the absence of exogenous treatments. In cultivars considered easy-to-root, the exogenous application of high concentrations of IBA (500 $6000 \mathrm{ppm})$ for short time periods $(10-20 \mathrm{sec})$ has shown to be effective and allows good rooting rates $(70-90 \%)$ which are compatible with commercial propagation. However, in difficult-to-root cultivars it became evident that other factors influence the cuttings' response, besides endogenous auxin levels. Although many parameters have been tested, including methods of application (solution, powder), concentrations, length of the treatment, and even other auxins (IAA, NAA), low rooting rates of these cuttings are still a persistent result.

In view of the above, many assays were performed with the goal of testing the effect of factors that are known to affect the rooting capacity of cuttings. Among these, some should be highlighted: the external application of polyamines (Rugini (1992), obtained good rooting rates with putrescine), the exogenous application of carbohydrates (Del Rio et al., (1986), show that external application is only effective during periods of natural deficiency), the nutritional status of mother plants (high nitrogen levels decrease rooting rates), the season (it seems established that spring and fall are the best seasons for rooting of semi-hardwood cuttings), the age of the starting plant material and that of the cutting (maintenance of mother plants with vigorous pruning is important and branches collected from the base of the stem are the best plant material for rooting). 
Very few articles report the quantification of endogenous levels of compounds that affect the formation of adventitious roots in olive. In such cases, it's shown that difficult-to-root cultivars struggle to control free auxin levels after the induction phase. The first results from genomic studies are now starting to emerge, with emphasis on the differential expression of AOX genes in easy- and difficult-to-root plants (Hedayati et al., 2015).

Developing a base of knowledge about adventitious rooting in olive to a level similar to what has been achieved in model species is certainly the main goal of future research studies. However, that doesn't necessarily require following the same steps. Sometimes, taking a step back allows us to learn from our mistakes and have a different view of what path to take.

For instance, the use of hardwood or semi-hardwood cuttings in fundamental studies on adventitious rooting is ill-advised, considering the extremely random response of this type of material, which is also dependent on uncontrollable factors (light, temperature, and humidity). In vitro culture techniques allow a much more effective control of such factors and therefore a much more homogenous response from the plant material.

It is impractical to keep using the base of the cuttings as analytical sample since it is known that only a small portion of cells participate in the process of adventitious root formation. The recent progress in techniques such as confocal microscopy and scanning electron microscopy, together with laser microdissection, opens up new possibilities for the study of pre-primordial and primordial cells.

Furthermore, it is also inefficient to continue quantifying biochemical compounds associated with adventitious root formation in the absence of a complementary genetic analysis of the process. Next Generation Sequencing (NSG) techniques (Tsai, 2013) are currently an extremely valuable tool in the search for genetic variability between individuals with different rooting behavior and can be a vital tool in studies on adventitious root formation.

As mentioned by Haissig and Davis (1994), "many researchers have collected numeric data, based on the hypothesis that enough numbers and properly compared will yield repeatable, interrelated 
sequences that can be used to decipher the most basic process underlying rooting. However, that hypothesis remains unproven. We have not been able to identify any underlying law(s) that our data and, therefore, rooting obeys."

A complex process demands an integrated approach. Only this way we can aspire to, sometime, be able to root any olive cultivar, where we want and how we want.

\section{Acknowledgements}

Authors would like to thank Isabel Brito for helpful insights and revisions. Authors acknowledge funding from the Portuguese Foundation for Science and Technology (FCT), through the projects PTDC/AGR AM/103377/2008 and PEst-C/AGR/UI0115/2011, through the Programa Operacional Regional do Alentejo (InAlentejo) Operation ALENT-07-0262-FEDER-001871 and through the Doctoral grant SFRH/BD/80513/2011. Authors also acknowledge funding from FEDER funds through the Competitiveness Factors Operational Program (COMPETE) and from the American Department of Energy (DOE) grant number DE-FG02-93ER20097 for the Center for Plant and Microbial Complex Carbohydrates at the CCRC. The first author would also like to acknowledge Parastoo Azadi at the Complex Carbohydrate Research Center (CCRC) for gracious support in her research while in the United States.

\section{References}

Abel, S., Nguyen, M.D., Chow, W., Theologis, A., 1995. ASC4, a Primary Indoleacetic Acid-responsive Gene Encoding 1-Aminocyclopropane-1-carboxylate Synthase in Arabidopsis thaliana Structural characterization, expression in Escherichia coli, and expression characteristics in response to auxin. Journal of Biological Chemistry 270, 19093-19099.

Ahkami, A.H., Lischewski, S., Haensch, K.-T., Porfirova, S., Hofmann, J., Rolletschek, H., Melzer, M., Franken, P., Hause, B., Druege, U., others, 2009. Molecular physiology of adventitious root formation in Petunia hybrida cuttings: involvement of wound response and primary metabolism. New Phytologist 181, 613-625.

Ahkami, A.H., Melzer, M., Ghaffari, M.R., Pollmann, S., Javid, M.G., Shahinnia, F., Hajirezaei, M.R., Druege, U., 2013. Distribution of indole-3-acetic acid in Petunia hybrida shoot tip cuttings and relationship between auxin transport, carbohydrate metabolism and adventitious root formation. Planta 238, 499-517.

Alabadi, D., Aguero, M.S., Pérez-Amador, M.A., Carbonell, J., 1996. Arginase, arginine decarboxylase, ornithine decarboxylase, and polyamines in tomato ovaries (changes in unpollinated ovaries and parthenocarpic fruits induced by auxin or gibberellin). Plant Physiology 112, 1237-1244.

Alcázar, R., Altabella, T., Marco, F., Bortolotti, C., Reymond, M., Koncz, C., Carrasco, P., Tiburcio, A.F., 2010. Polyamines: molecules with regulatory functions in plant abiotic stress tolerance. Planta 231, 1237-49. 
Alguacil, M., Hernández, J.A., Caravaca, F., Portillo, B., Roldan, A., 2003. Antioxidant enzyme activities in shoots from three mycorrhizal shrub species afforested in a degraded semi-arid soil. Physiologia Plantarum 118, 562-570.

Ali, A., Ahmad, T., Abbasi, N.A., Hafiz, I.A., 2009. Effect of different concentrations of auxins on in vitro rooting of olive cultivar "Moraiolo". Pakistan Journal of Botany 41, 1223-1231.

Ali, A., Jarvis, B., 1988. Effects of auxin and boron on nucleic acid metabolism and cell division during adventitious root regeneration. New phytologist 383-391.

Altamura, M., 1996. Root histogenesis in herbaceous and woody explants cultured in vitro. A critical review. Agronomie-Sciences des Productions Vegetales et de l'Environnement 16, 589-602.

Altamura, M., Capitani, F., Cerchia, R., Falasca, G., Bagni, N., 1993. Cytological events induced by the inhibition of polyamine biosynthesis in thin cell layers of tobacco. Protoplasma 175, 9-16.

Altamura, M., Torrigiani, P., Capitani, F., Scaramagli, S., Bagni, N., 1991. De novo root formation in tobacco thin layers is affected by inhibition of polyamine biosynthesis. Journal of experimental botany 42, 1575-1582.

Altman, A., 1989. Polyamines and plant hormones, in: Bachrach, U and Heimer, YM (Ed.), The Physiology of Polyamines. CRC Press Boca Raton, Florida, pp. 121-145.

Alvarez, R., Nissen, S.J., Sutter, E.G., 1989. Relationship between indole-3-acetic acid levels in apple (Malus pumila Mill) rootstocks cultured in vitro and adventitious root formation in the presence of indole-3-butyric acid. Plant physiology $89,439-443$.

Anderson, M., Habiger, J., 2012. Characterization and identification of productivity-associated rhizobacteria in wheat. Applied and environmental microbiology 78, 4434-4446.

Arbuscular Mycorrhizas http://www.sft66.com/fungi/html/vam.html (accessed 8.13.15).

Aslmoshtaghi, E., Shahsavar, A., 2010. Endogenous soluble sugars, starch contents and phenolic compounds in easyand difficult-to-root olive cuttings. Journal of Biological \& Environmental Sciences 4, 83-86.

Auderset, G., Gavillet, S., Micheli, J., O’Rourke, J., Ribaux, M., Moncousin, C., 1994. Histological analysis and the evolution of biochemical markers during the in vitro rooting of Malus domestica Borkh.'Jork 9'. Advances in horticultural science $8,5-10$.

Avidan, B., Lavee, S., 1978. Physiological aspects of the rooting ability of olive cultivars. Acta Horticulturae 79, 93102. doi:10.17660/ActaHortic.1978.79.10

Awan, A.A., Ullah, E., Abbas, S.J., Khan, O., Masroor, S., 2012. Growth response of various olive cultivars to different cutting lengths. Pakistan Journal of Agricultural Sciences 49, 315-318.

Ayoub, S., Qrunfleh, M.M., 2008. A Study on Some Physiological and Anatomical Aspects of Rooting'Nabali'and'Raseei'Olive Semi-Hardwood Stem Cuttings. Acta Horticulturae 773, 221-226.

Ayoub, S.J., Qrunfleh, M.M., 2006. Anatomical Aspects of Rooting "Nabali”and "Raseei”Olive Semi-Hardwood Stem Cuttings. Jordan Journal of Agricultural Sciences 2, 16-27.

Azcón-Aguilar, C., Barea, J., 1997. Applying mycorrhiza biotechnology to horticulture: significance and potentials. Scientia Horticulturae 68, 1-24.

Bais, H.P., Ravishankar, G., 2002. Role of polyamines in the ontogeny of plants and their biotechnological applications. Plant Cell, Tissue and Organ Culture 69, 1-34.

Bajguz, A., Piotrowska, A., 2009. Conjugates of auxin and cytokinin. Phytochemistry 70, 957-969.

Bakr, E., Selim, H., Nour, G., Gabr, M., 1977. Developmental anatomy of adventitious roots on stem cuttings of Wetaken" olive cultivar. Egyptian Journal of Horticulture 4, 91-7.

Bandurski, R.S., Cohen, J.D., Slovin, J.P., Reinecke, D.M., 1995. Auxin biosynthesis and metabolism, in: Plant Hormones. Springer, pp. 39-65. doi:10.1007/978-94-011-0473-9_3

Bansal, M., Nanda, K., 1981. IAA oxidase activity in relation to adventitious root formation on stem cuttings of some forest tree species. Experientia 37, 1273-1274. 
Baraldi, P., Bertazza, G., Bregoli, A., Fasolo, F., Rotondi, A., Predieri, S., Serafini-Fracassini, D., Slovin, J., Cohen, J., 1995. Auxins and polyamines in relation to differential in vitro root induction on microcuttings of two pear cultivars. Journal of Plant Growth Regulation 14, 49-59.

Bartolini, G., Petruccelli, R., Pestelli, P., Bernardi, R., Durante, M., 2008. Preliminary study on in vivo rooting of two Olea europaea L. genotypes. Acta Horticulturae 791, 191-196.

Basak, U., Das, A., Das, P., 2000. Rooting response in stem cuttings from five species of mangrove trees: effect of auxins and enzyme activities. Marine Biology 136, 185-189.

Bati, C., Fodale, A., Mulé, R., Trombino, T., 1999. Trials to increase in vitro rooting of Olea europaea L. cuttings. Acta Horticulturae 474, 91-96. doi:10.17660/ActaHortic.1999.474.15

Batish, D.R., Singh, H.P., Kaur, S., Kohli, R.K., Yadav, S.S., 2008. Caffeic acid affects early growth, and morphogenetic response of hypocotyl cuttings of mung bean (Phaseolus aureus). Journal of Plant Physiology 165, 297-305.

Batten, D., Mullins, M., 1978. Ethylene and adventitious root formation in hypocotyl segments of etiolated mung-bean (Vigna radiata (L.) Wilczek) seedlings. Planta 138, 193-197.

Bellamine, J., Penel, C., Greppin, H., Gaspar, T., 1998. Confirmation of the role of auxin and calcium in the late phases of adventitious root formation. Plant Growth Regulation 26, 191-194.

Bellini, C., Pacurar, D.I., Perrone, I., 2014. Adventitious roots and lateral roots: similarities and differences. Annual Review of Plant Biology 65, 639-666.

Ben-Shalom, N., Kahn, V., Harel, E., Mayer, A.M., 1977. Catechol oxidase from green olives: properties and partial purification. Phytochemistry 16, 1153-1158.

Berthon, J., Boyer, N., Gaspar, T., 1987. Sequential rooting media and rooting capacity of Sequoiadendron giganteum in vitro. Peroxidase activity as a marker. Plant Cell Reports 6, 341-344.

Berthon, J.-Y., Ben Tahar, S., Gaspar, T., Boyer, N., 1990. Rooting phases of shoots of Sequoiadendron giganteum in vitro and their requirements. Plant physiology and biochemistry 28, 631-638.

Bhattacharya, N., Kumar, A., 1980. Physiological and biochemical studies associated with adventitious root formation in, Phaseolus mungo L. in relation to auxin - phenol synergism. Biochemie und Physiologie der Pflanzen 175, 421435.

Binet, M., Lemoine, M., Martin, C., Chambon, C., Gianinazzi, S., 2007. Micropropagation of olive (Olea europaea L.) and application of mycorrhiza to improve plantlet establishment. In Vitro Cellular \& Developmental Biology-Plant $43,473-478$.

Biondi, S., Diaz, T., Iglesias, I., Gamberini, G., Bagni, N., 1990. Polyamines and ethylene in relation to adventitious root formation in Prunus avium shoot cultures. Physiologia Plantarum 78, 474-483. doi:10.1111/j.13993054.1990.tb09066.x

Blakeslee, J.J., Peer, W.A., Murphy, A.S., 2005. Auxin transport. Current Opinion in Plant Biology 8, 494-500.

Blakesley, D., Weston, G., Hall, J., 1991. The role of endogenous auxin in root initiation. Plant Growth Regulation 10, 341-353.

Blazich, F.A., 1988. Mineral nutrition and adventitious rooting, in: Davis, T. D. and Haissig B. E. and Sankhla N. (Ed.), Adventitious Root Formation in Cuttings, Advances in Plant Science. Dioscorides Press, Portland, USA, pp. 6169.

Blythe, E.K., Sibley, J.L., Tilt, K.M., Ruter, J.M., 2007. Methods of auxin application in cutting propagation: A review of 70 years of scientific discovery and commercial practice. Journal of Environmental Horticulture 25, 166.

Bressan, P., Kim, Y., Hyndman, S., Hasegawa, P., Bressan, R., 1982. Factors affecting in vitro propagation of rose. Journal of the American Society for Horticultural Science 107, 979-990.

Brown, S.D., Utturkar, S.M., Klingeman, D.M., Johnson, C.M., Martin, S.L., Land, M.L., Lu, T.-Y.S., Schadt, C.W., Doktycz, M.J., Pelletier, D.A., 2012. Twenty-one genome sequences from Pseudomonas species and 19 genome sequences from diverse bacteria isolated from the rhizosphere and endosphere of Populus deltoides. Journal of Bacteriology 194, 5991-5993. 
Bustos, M.E., 2012. Efecto de la inoculación con hongos micorrícicos arbusculares en plantines de olivo sobre diferentes sustratos. PhD thesis. Universidad de Buenos Aires, Argentina.

Caballero, J., Nahlawi, N., 1979. Influence of carbohydrates and washing with water on the rooting of the Gordal cultivar of the olive (Olea europaea L.). Anais Instituto Nacional de Investigaciones Agrarias, Serie Producción Vegetal, Madrid 11, 219-230.

Caboni, E., Tonelli, M., Lauri, P., Iacovacci, P., Kevers, C., Damiano, C., Gaspar, T., 1997. Biochemical aspects of almond microcuttings related to in vitro rooting ability. Biologia Plantarum 39, 91-97.

Calamar, A., De Klerk, G.-J., 2002. Effect of sucrose on adventitious root regeneration in apple. Plant Cell, Tissue and Organ Culture 70, 207-212.

Calvente, R., Cano, C., Ferrol, N., Azcón-Aguilar, C., Barea, J., 2004. Analysing natural diversity of arbuscular mycorrhizal fungi in olive tree (Olea europaea L.) plantations and assessment of the effectiveness of native fungal isolates as inoculants for commercial cultivars of olive plantlets. Applied Soil Ecology 26, 11-19.

Campa, A., 1991. Biological roles of plant peroxidases: known and potential function, in: Everse, J. and Everse, K. and Grisham, M. B. (Ed.), Peroxidases in Chemistry and Biology. CRC Press, Boca Raton, FL, pp. 25-50.

Camprubi, A., Calvet, C., 1996. Isolation and screening of mycorrhizal fungi from citrus nurseries and orchards and inoculation studies. HortScience 31, 366-369.

Caravaca, F., Diaz, E., Barea, J., Azcón-Aguilar, C., Roldan, A., 2003. Photosynthetic and transpiration rates of Olea europaea subsp. sylvestris and Rhamnus lycioides as affected by water deficit and mycorrhiza. Biologia Plantarum 46, 637-639.

Casimiro, I., Beeckman, T., Graham, N., Bhalerao, R., Zhang, H., Casero, P., Sandberg, G., Bennett, M.J., 2003. Dissecting Arabidopsis lateral root development. Trends in Plant Science 8, 165-171.

Chaari-Rkhis, A., Trigui, A., Drira, N., 1997. Micropropagation of Tunisian cultivars olive trees: preliminary results. Acta Horticulturae 474, 79-82. doi:10.17660/ActaHortic.1999.474.12

Chang, W.-C., Chan, S.-J., 1976. Cytochemical studies on the changes of nuclear histones and RNA synthesis activity of adventitous root initials in mung bean hypocotyl cuttings. Bot Bull Acad Sinica 17, 192-202.

Chas, E., 1994. Atlas de la flore des Hautes-Alpes. Parc National des Ecrins.

Cheniany, M., Ebrahimzadeh, H., Masoudi-nejad, A., Vahdati, K., Leslie, C., 2010. Effect of endogenous phenols and some antioxidant enzyme activities on rooting of Persian walnut (Juglans regia L.). African Journal of Plant Science 4, 479-487.

Ciampi, C., Gellini, R., 1963. The Origin and Development of Adventitious Roots in Olea europaea: The Importance of Anatomical Structure in Rootlet Development. G. Bot. Ital 70, 62-74.

Ciou, J.-Y., Lin, H.-H., Chiang, P.-Y., Wang, C.-C., Charles, A.L., 2011. The role of polyphenol oxidase and peroxidase in the browning of water caltrop pericarp during heat treatment. Food Chemistry 127, 523-527.

Citernesi, A., Vitagliano, C., Giovannetti, M., 1998. Plant growth and root system morphology of Olea europaea L. rooted cuttings as influenced by arbuscular mycorrhizas. Journal of Horticultural Science \& Biotechnology 75, $647-654$.

Cohen, S.S., 1998. Guide to the Polyamines. Oxford University Press, New York.

Collet, G., 1985. Enracinement ameliore lors de la production in vitro de rosiers. Revue Suisse de Viticulture, Arboriculture, Horticulture.

Constabel, C.P., Barbehenn, R., 2008. Defensive roles of polyphenol oxidase in plants, in: Induced Plant Resistance to Herbivory. Springer, pp. 253-270.

Cooper, W.C., 1935. Hormones in relation to root formation on stem cuttings. Plant Physiology 10, 789.

Couée, I., Hummel, I., Sulmon, C., Gouesbet, G., El Amrani, A., 2004. Involvement of polyamines in root development. Plant Cell Tissue and Organ Culture 76, 1-10. 
Cozza, R., Turco, D., Bati, C.B., Bitonti, M.B., 1997. Influence of growth medium on mineral composition and leaf histology in micropropagated plantlets of Olea europaea. Plant Cell, Tissue and Organ Culture 51, 215-223.

Cristofori, V., Rouphael, Y., Rugini, E., 2010. Collection time, cutting age, IBA and putrescine effects on root formation in Corylus avellana L. cuttings. Scientia Horticulturae 124, 189-194.

Da Costa, C.T., de Almeida, M.R., Ruedell, C.M., Schwambach, J., Maraschin, F.S., Fett-Neto, A.G., 2013. When stress and development go hand in hand: main hormonal controls of adventitious rooting in cuttings. Frontiers in Plant Science 4.

Da Silva, L.F.O., De Oliveira, A.F., Pio, R., Zambon, C., Oliveira, D.L., 2012. Enraizamento de estacas semilenhosas de cultivares de oliveira. Bragantia 71, 488-492.

Dardanelli, M.S., Manyani, H., González-Barroso, S., Rodriguez-Carvajal, M.A., Gil-Serrano, A.M., Espuny, M.R., López-Baena, F.J., Bellogin, R.A., Megias, M., Ollero, F.J., 2010. Effect of the presence of the plant growth promoting rhizobacterium (PGPR) Chryseobacterium balustinum Aur9 and salt stress in the pattern of flavonoids exuded by soybean roots. Plant and Soil 328, 483-493.

Das, B., Tantry, F., Srivastava, K., 2006. Rooting response of olive stem cuttings under zero energy environment. Indian Journal of Horticulture 63, 209-212.

Davis, T., Sankhla, N., Walser, R., Upadhyaya, A., 1985. Promotion of adventitious root formation on cuttings by paclobutrazol. HortScience 20, 883-884.

Dawson, J.H., 1988. Probing structure-function relations in heme-containing oxygenases and peroxidases. Science 240, 433-439.

De Klerk, G.-J., 1996. Markers of adventitious root formation. Agronomie 16, 609-616.

De Klerk, G.-J., Keppel, M., Ter Brugge, J., Meekes, H., 1995. Timing of the phases in adventitous root formation in apple microcuttings. Journal of Experimental Botany 46, 965-972.

De Klerk, G.-J., van der Krieken, W., de Jong, J.C., 1999. Review the formation of adventitious roots: new concepts, new possibilities. In Vitro Cellular \& Developmental Biology-Plant 35, 189-199.

De Oliveira, A., Pasqual, M., Chalfun, N.N.J., Regina, M. de A., Rincón, C.D.R., 2003. Enraizamento de estacas semilenhosas de oliveira sob efeito de diferentes épocas, substratos e concentrações de ácido indolbutirico. Ciência e Agrotecnologia 27, 117-125.

De Oliveira, A.F., Chalfun, N.N.J., Alvarenga, Â.A., Vieira Neto, J., Pio, R., Oliveira, D.L. de, 2009. Estaquia de oliveira em diferentes épocas, substratos e doses de AIB diluído em $\mathrm{NaOH}$ e álcool. Ciência e Agrotecnologia 33, $79-85$.

De Oliveira, A.F., Pasqual, M., Chalfun, N.N.J., Regina, M. de A., Rincón, C.D.R., 2003. Influência do número de nós em estacas semilenhosas de oliveira (Olea europaea L.) no enraizamento sob câmara de nebulização. Ciência e Agrotecnologia 27, 332-338.

De Oliveira, L.F., Quoirin, M., Koehler, H.S., Amano, E., Higa, A.R., Ribas, L.L.F., 2013. Propagation from axillary buds and anatomical study of adventitious roots of Pinus taeda L. African Journal of Biotechnology 12, 5413.

Del Rio, C., 1989. Influencia de los hidratos de carbono y de la presencia del fruto en el enraizamiento de olivo por estaquillado semileñoso. PhD thesis, Spain.

Del Rio, C., Caballero, J., L., R., 1986. Influencia de la sacarosa sobre el enraizamiento de estaquillas vegetativas y fructíferas de olivo "Picual", in: Actas Del II Congreso Nacional de La Sociedad Española de Ciencias Horticolas. Córdoba, Spain, pp. 87-93.

Del Rio, C., Rallo, L., Caballero, J., 1991. Effects of carbohydrate content on the seasonal rooting of vegetative and reproductive cuttings of olive. Journal of Horticultural Science.

Della Rovere, F., Fattorini, L., D'Angeli, S., Veloccia, A., Falasca, G., Altamura, M., 2013. Auxin and cytokinin control formation of the quiescent centre in the adventitious root apex of arabidopsis. Annals of Botany 112, 1935-1407.

Denaxa, N., Vemmos, S., Roussos, P., Kostelenos, G., 2010. The effect of IBA, NAA and carbohydrates on rooting capacity of leafy cuttings in three olive cultivars (Olea europaea L.). Acta Horticulturae 924, 101-109. doi:10.17660/ActaHortic.2011.924.12 
Denaxa, N.-K., Roussos, P.A., Vemmos, S.N., 2014. The possible role of polyamines to the recalcitrance of "Kalamata" olive leafy cuttings to root. Journal of Plant Growth Regulation 33, 579-589.

Denaxa, N.-K., Vemmos, S.N., Roussos, P.A., 2012. The role of endogenous carbohydrates and seasonal variation in rooting ability of cuttings of an easy and a hard to root olive cultivars (Olea europaea L.). Scientia Horticulturae $143,19-28$.

Desai, H.V., Mehta, A.R., 1985. Changes in polyamine levels during shoot formation, root formation, and callus induction in cultured Passiflora leaf discs. Journal of Plant Physiology 119, 45-53.

Di, D.-W., Zhang, C., Luo, P., An, C.-W., Guo, G.-Q., 2015. The biosynthesis of auxin: how many paths truly lead to IAA? Plant Growth Regulation 1-11.

Dridi, B., 2003. Un système intégré de micropropagation de l'artichaut (Cynara scolymus L.).

Druart, P., 1997. Optimization of culture media for in vitro rooting of Malus domestica Borkh. cv. Compact Spartan. Biologia Plantarum 39, 67-77.

Druege, U., 2009. Involvement of carbohydrates in survival and adventitious root formation of cuttings within the scope of global horticulture, in: Niemi, K. and Scagel, C. (Ed.), Adventitious Root Formation of Forest Trees and Horticultural Plants-From Genes to Applications. Research Signpost, Kerala, pp. 187-208.

Druege, U., Franken, P., Lischewski, S., Ahkami, A.H., Zerche, S., Hause, B., Hajirezaei, M.R., 2014. Transcriptomic analysis reveals ethylene as stimulator and auxin as regulator of adventitious root formation in petunia cuttings. Frontiers in Plant Science 5, 1-19.

Druege, U., Zerche, S., Kadner, R., Ernst, M., 2000. Relation between nitrogen status, carbohydrate distribution and subsequent rooting of chrysanthemum cuttings as affected by pre-harvest nitrogen supply and cold-storage. Annals of Botany 85, 687-701.

Dunberg, A., Hsihan, S., Sandberg, G., 1981. Auxin dynamics and the rooting of cuttings of Pinus sylvestris. Plant Physiology 67.

Ebrahimzadeh, H., Motamed, N., Rastgar-Jazii, F., Montasser-Kouhsari, S., Shokraii, E.H., 2003. Oxidative enzyme activities and soluble protein content in leaves and fruits of olives during ripening. Journal of Food Biochemistry 27, 181-196.

Epstein, E., Ackerman, A., 1993. Transport and metabolism of indole-3-butyric acid in cuttings of Leucadendron discolor. Plant Growth Regulation 12, 17-22.

Epstein, E., Chen, K.-H., Cohen, J.D., 1989. Identification of indole-3-butyric acid as an endogenous constituent of maize kernels and leaves. Plant Growth Regulation 8, 215-223.

Epstein, E., Lavee, S., 1984. Conversion of indole-3-butyric acid to indole-3-acetic acid by cuttings of grapevine (Vitis vinifera) and olive (Olea europea). Plant and Cell Physiology 25, 697-703.

Epstein, E., Zilkah, S., Faingersh, G., Rotebaum, A., 1993. Transport and metabolism of indole-3-butyric acid in easyand difficult-to-root cuttings of sweet cherry (Prunus avium L.). Acta Horticulturae 329, 292-295.

Escribano, J., Gandía-Herrero, F., Caballero, N., Pedreño, M.A., 2002. Subcellular localization and isoenzyme pattern of peroxidase and polyphenol oxidase in beet root (Beta vulgaris L.). Journal of Agricultural and Food Chemistry 50, 6123-6129.

Espín, J.C., Trujano, M.F., Tudela, J., García-Cánovas, F., 1997. Monophenolase activity of polyphenol oxidase from Haas avocado. Journal of Agricultural and Food Chemistry 45, 1091-1096.

Estaún, V., Camprubi, A., Calvet, C., Pinochet, J., 2003. Nursery and field response of olive trees inoculated with two arbuscular mycorrhizal fungi, Glomus intraradices and Glomus mosseae. Journal of the American Society for Horticultural Science 128, 767-775.

Eveland, A.L., Jackson, D.P., 2011. Sugars, signalling, and plant development. Journal of Experimental Botany 63, $3367-3377$

Fabbri, A., Bartolini, G., Lambardi, M., Kailis, S., others, 2004. Olive propagation manual. CSIRO.

Faivre-Rampant, O., Kevers, C., Bellini, C., Gaspar, T., 1998. Peroxidase activity, ethylene production, lignification and growth limitation in shoots of a nonrooting mutant of tobacco. Plant Physiology and Biochemistry 36, 873- 
Faivre-Rampant, O., Kevers, C., Dommes, J., Gaspar, T., 2000. The recalcitrance to rooting of the micropropagated shoots of the rac tobacco mutant: Implications of polyamines and of the polyamine metabolism. Plant Physiology and Biochemistry 38, 441-448.

Fang, W.-C., Kao, C.H., 2000. Enhanced peroxidase activity in rice leaves in response to excess iron, copper and zinc. Plant Science 158, 71-76.

Fett-Neto, A.G., Fett, J.P., Goulart, L.W.V., Pasquali, G., Termignoni, R.R., Ferreira, A.G., 2001. Distinct effects of auxin and light on adventitious root development in Eucalyptus saligna and Eucalyptus globulus. Tree Physiology $21,457-464$.

Fontanazza, G., Rugini, E., 1977. Effect of leaves and buds removal on rooting ability of olive tree cuttings. Olea, Córdoba 2, 9-28.

Foong, T.W., Barnes, M.F., 1981. The levels of reserve metabolites and oxidative enzymes in the cuttings of easy-toroot and difficult-to-root rhododendrons. Biochemie und Physiologie der Pflanzen 176, 206-216.

Ford, Y.-Y., Bonham, E., Cameron, R., Blake, P., Judd, H., Harrison-Murray, R., 2001. Adventitious rooting: examining the role of auxin in an easy-and a difficult-to-root plant. Plant Growth Regulation 36, 149-159.

Fouad, M., Fayek, M., Selim, H., El-Sayed, M., 1990. Rooting of eight olive cultivars under mist. Acta Horticulturae $286,57-60$

Frenkel, C., Hess, C.E., 1974. Isozymic changes in relation to root initiation in mung bean. Canadian Journal of Botany $52,295-297$

Friedman, R., Altman, A., Bachrach, U., 1982. Polyamines and root formation in mung bean hypocotyl cuttings I. Effects of exogenous compounds and changes in endogenous polyamine content. Plant Physiology 70, 844-848.

Friedman, R., Altman, A., Bachrach, U., 1985. Polyamines and root formation in mung bean hypocotyl cuttings II. Incorporation of precursors into polyamines. Plant Physiology 79, 80-83.

Gad, A.E., Ben-Efraim, I., 1988. Promotion of adventitious root formation by 4-chlororesorcinol: A polyphenol oxidase inhibitor. Plant Growth Regulation 7, 91-99.

Galston, A.W., Bonner, J., Baker, R.S., 1953. Flavoprotein and peroxidase as components of the indoleacetic acid oxidase system of peas. Archives of Biochemistry and Biophysics 42, 456-470.

Galston, A.W., Sawhney, R.K., 1990. Polyamines in plant physiology. Plant Physiology 94, 406-10.

Ganz, T., Kailis, S., Abbott, L., 2002. Mycorrhizal colonization and its effect on growth, phosphorus uptake and tissue phenolic content in the European olive (Olea europaea L.). Advances in Horticultural Science 16, 109-116.

Garcia, J., Troncoso, J., Sarmiento, R., Troncoso, A., 2002. Influence of carbon source and concentration on the in vitro development of olive zygotic embryos and explants raised from them. Plant Cell, Tissue and Organ Culture 69, 95100 .

García-Gómez, M., Sánchez-Romero, C., Barceló-Munoz, A., Heredia, A., Pliego-Alfaro, F., 1994. Levels of endogenous indole-3-acetic acid and indole-3-acetyl-aspartic acid during adventitious rooting in avocado microcuttings. Journal of Experimental Botany 45, 865-870. doi:10.1093/jxb/45.6.865

Gaspar, T., Kevers, C., Hausman, J., Berthon, J., Ripetti, V., 1992. Practical uses of peroxidase activity as a predictive marker of rooting performance of micropropagated shoots. Agronomie 12, 757-765.

Gaspar, T., Kevers, C., Hausman, J.-F., 1997. Indissociable chief factors in the inductive phase of adventitious rooting, in: Altman, A. and Waisel, Y. (Ed.), Biology of Root Formation and Development. Plenum Press, New York, USA.

Gaspar, T., Kevers, C., Hausman, J.F., Ripetti, V., 1994. Peroxidase activity and endogenous free auxin during adventitious root formation, in: Lumsden, P.J., Nicholas, J.R. and Davies (Ed.), Physiology, Growth and Development of Plants in Culture. Kluwer Academic Publishers, Dordrecht, The Netherlands, pp. 289-298.

Gatineau, F., Fouche, J., Kevers, C., Hausman, J., Gaspar, T., 1997. Quantitative variations of indolyl compounds including IAA, IAA-aspartate and serotonin in walnut microcuttings during root induction. Biologia plantarum 39, 131-137. 
Geiss, G., Gutierrez, L., Bellini, C., 2009. Adventitious root formation: new insights and perspectives, in: Beeckman, Tom (Ed.), Annual Plant Reviews: Root Development. Wiley-Blackwell Oxford, pp. 127-156. doi:10.1002/9781444310023.ch5

Gellini, R., 1965. Seasonal variation in the rooting of olive cuttings. Atti Giorn. Stud. Prop. Spec, legn., Pisa, 1964. $76-86$.

Geneve, R.L., Kester, S.T., 1991. Polyamines and adventitious root formation in the juvenile and mature phase of English ivy. Journal of Experimental Botany 42, 71-75. doi:10.1093/jxb/42.1.71

George, E.F., De Klerk, G.-J., 2008. The components of plant tissue culture media I: macro-and micro-nutrients, in: Plant Propagation by Tissue Culture. Springer, pp. 65-113.

Gibson, S.I., 2004. Sugar and phytohormone response pathways: navigating a signalling network. Journal of Experimental Botany 55, 253-264.

Gibson, S.I., 2005. Control of plant development and gene expression by sugar signaling. Current Opinion in Plant Biology 8, 93-102.

Goldbach, H., Amberger, A., 1986. Influence of boron deficiency on 3H indole-3yl-acetic acid uptake and efflux in cell cultures of Daucus carota L. Plant Growth Regulation 4, 81-86.

Gonçalves, J.C., Diogo, G., Amâncio, S., 1998. In vitro propagation of chestnut (Castanea sativa x C. crenata: Effects of rooting treatments on plant survival, peroxidase activity and anatomical changes during adventitious root formation. Scientia Horticulturae 72, 265-275.

Gonçalves, J.C., Diogo, G., Coelho, M.T., Vidal, N., Amâncio, S., 2008. Quantitation of endogenous levels of IAA, IAAsp and IBA in micro-propagated shoots of hybrid chestnut pre-treated with IBA. In Vitro Cellular \& Developmental Biology-Plant 44, 412-418.

Gorter, C.J., 1969. Auxin-Synergists in the Rooting of Cuttings. Physiologia Plantarum 22, 497-502. doi:10.1111/j.1399-3054.1969.tb07403.x

Goupy, P., Fleuriet, A., Amiot, M.J., Macheix, J.J., 1991. Enzymic browning, oleuropein content, and diphenol oxidase activity in olive cultivars (Olea europaea L.). Journal of Agricultural and Food chemistry 39, 92-95.

Grigoriadou, K., Vasilakakis, M., Eleftheriou, E.P., 2002. In vitro propagation of the Greek olive cultivar "Chondrolia Chalkidikis". Plant Cell, Tissue and Organ culture 71, 47-54.

Gu, Y., Deng, X., Zhan, J., Shi, D., Wang, M., 2004. Effects of IBA and NAA on POD and PPO in the development of adventitious root of Elaeocarpus sylvestris. Subtropical Plant Science 33, 8-9.

Güneş, T., 2000. Peroxidase and IAA-oxidase activities during rooting in cuttings of three poplar species. Turkish Journal of Botany 24, 97-101.

Gutierrez, L., Bussell, J.D., Pacurar, D.I., Schwambach, J., Pacurar, M., Bellini, C., 2009. Phenotypic plasticity of adventitious rooting in Arabidopsis is controlled by complex regulation of AUXIN RESPONSE FACTOR transcripts and microRNA abundance. The Plant Cell 21,3119-3132.

Gutierrez, L., Mongelard, G., Floková, K., Pacurar, D.I., Novák, O., Staswick, P., Kowalczyk, M., Pacurar, M., Demailly, H., Geiss, G., Bellini, C., 2012. Auxin controls Arabidopsis adventitious root initiation by regulating jasmonic acid homeostasis. The Plant Cell Online 24, 2515-2527.

Haissig, B.E., Davis, T.D., 1994. A historical evaluation of adventitious rooting research to 1993, in: Biology of Adventitious Root Formation. Springer, pp. 275-331.

Haq, I.U., Ahmad, T., Hafiz, I.A., Abbasi, N.A., 2009. Influence of micro cutting sizes and IBA Concentrations on in vitro rooting of olive cv. "Dolce agogia". Pakistan Journal of Botany 41, 1213-1222.

Harbage, J.F., Stimart, D.P., Evert, R.F., 1993. Anatomy of Adventitious Root Formation in Microcuttings of Malus domestica Borkh.Gala'. Journal of the American Society for Horticultural Science 118, 680-688.

Hartmann, H., Kester, D., Davies, F., 1990. Plant propagation. Principles and practices., 5th ed. Prentice Hall, Englewood Clipps, NJ, USA.

Hausman, J., 1993. Changes in peroxidase activity, auxin level and ethylene production during root formation by poplar shoots raised in vitro. Plant Growth Regulation 13, 263-268. 
Hausman, J.-F., Gevers, C., Gaspar, T., 1994. Involvement of putrescine in the inductive rooting phase of poplar shoots raised in vitro. Physiologia Plantarum 92, 201-206. doi:10.1111/j.1399-3054.1994.tb05327.x.

Hausman, J.-F., Kevers, C., Gaspar, T., 1995a. Auxin-polyamine interaction in the control of the rooting inductive phase of poplar shoots in vitro. Plant Science 110, 63-71.

Hausman, J.-F., Kevers, C., Gaspar, T., 1995b. Putrescine control of peroxidase activity in the inductive phase of rooting in poplar shoots in vitro, and the adversary effect of spermidine. Journal of Plant Physiology 146, 681-685.

Hedayati, V., Mousavi, A., Razavi, K., Cultrera, N., Alagna, F., Mariotti, R., Hosseini-Mazinani, M., Baldoni, L., 2015. Polymorphisms in the AOX2 gene are associated with the rooting ability of olive cuttings. Plant Cell Reports 1-14.

Heloir, M.-C., Kevers, C., Hausman, J.-F., Gaspar, T., 1996. Changes in the concentrations of auxins and polyamines during rooting of in-vitro-propagated walnut shoots. Tree Physiology 16, 515-519.

Hicks, G.S., 1987. Adventitious rooting of apple microcuttings in vitro: an anatomical study. Canadian Journal of Botany 65, 1913-1920.

Hind, G., Marshak, D.R., Coughlan, S.J., 1995. Spinach thylakoid polyphenol oxidase: cloning, characterization, and relation to a putative protein kinase. Biochemistry $34,8157-8164$.

Hiraga, S., Sasaki, K., Ito, H., Ohashi, Y., Matsui, H., 2001. A large family of class III plant peroxidases. Plant and Cell Physiology 42, 462-468.

Hochholdinger, F., Park, W.J., Sauer, M., Woll, K., 2004. From weeds to crops: genetic analysis of root development in cereals. Trends in Plant Science 9, 42-48.

Hochholdinger, F., Zimmermann, R., 2008. Conserved and diverse mechanisms in root development. Current Opinion in Plant Biology 11, 70-74.

Hu, H., Brown, P.H., Labavitch, J.M., 1996. Species variability in boron requirement is correlated with cell wall pectin. Journal of Experimental Botany 47, 227-232.

İsfendiyaroğlu, M., Özeker, E., 2008. Rooting of Olea europaea "Domat" cuttings by auxin and salicylic acid treatments. Pakistan Journal of Botany 40, 1135-1141.

Jarvis, B., 1986. Endogenous control of adventitious rooting in non-woody cuttings., in: New Root Formation in Plants and Cuttings. Springer, pp. 191-222.

Jarvis, B., Booth, A., 1981. Influence of indole-butyric acid, boron, myo-inositol, vitamin D2 and seedling age on adventitious root development in cuttings of Phaseolus aureus. Physiologia Plantarum 53, 213-218.

Jarvis, B., Shaheed, A., 1987. Adventitious root formation in relation to irradiance and auxin supply. Biologia Plantarum 29, 321-333.

Jarvis, B., Shannon, P., Yasmin, S., 1983. Involvement of polyamines with adventitious root development in stem cuttings of mung bean. Plant and Cell Physiology 24, 677-683.

Jarvis, B., Yasmin, S., Coleman, M., 1985. RNA and protein metabolism during adventitious root formation in stem cuttings of Phaseolus aureus. Physiologia Plantarum 64, 53-59. doi:10.1111/j.1399-3054.1985.tb01212.x.

Jarvis, S., 1984. The effects of nitrogen supply on the absorption and distribution of copper in red clover (Trifolium pratense L.) grown in flowing solution culture with a low, maintained concentration of copper. Annals of Botany $53,153-161$.

Jasik, J., De Klerk, G.-J., 1997. Anatomical and ultrastructural examination of adventitious root formation in stem slices of apple. Biologia Plantarum 39, 79-90.

Jiménez, M., García-Carmona, F., 1999. Oxidation of the flavonol quercetin by polyphenol oxidase. Journal of Agricultural and Food Chemistry 47, 56-60.

Josten, P., Kutschera, U., 1999. The micronutrient boron causes the development of adventitious roots in sunflower cuttings. Annals of Botany 84, 337-342.

Kapoor, R., Sharma, D., Bhatnagar, A., 2008. Arbuscular mycorrhizae in micropropagation systems and their potential applications. Scientia Horticulturae 116, 227-239. 
Kaur-Sawhney, R., Tiburcio, A.F., Altabella, T., Galston, A.W., 2003. Polyamines in plants: an overview. Journal of Cellular and Molecular Biology 2, 1-12.

Kevers, C., Gaspar, T., Hausman, J.-F., 1997a. Involvement of putrescine and of its catabolic pathway in the induction of rooting of walnut shoots in vitro, in: Altman, A. and Waisel, Y. (Ed.), Biology of Root Formation and Development. Plenum Press, New York, USA, pp. 161-162.

Kevers, C., Hausman, J., Faivre-Rampant, O., Dommes, J., Gaspar, T., 2009. What we have learned about the physiology of in vitro adventitious rooting of woody plants and how it relates to improvements in the practice. Adventitious root formation of forest trees and horticultural plants-from genes to applications., in: Adventitious root formation of forest trees and horticultural plants - from genes to applications, Research Signpost, Kerala, India, pp. 209-225

Kevers, C., Hausman, J.-F., Faivre-Rampant, O., Evers, D., Gaspar, T., 1997b. Hormonal control of adventitious rooting: progress and questions. Angewandte Botanik 71, 71-79.

Khabou, W., 2002. The effect of orthotropic and plagiotropic shoots on semi-hard wood cuttings rhizogenesis of some tunisian olive cultivars. Acta Horticulturae 586, 887-890. doi:10.17660/ActaHortic.2002.586.193

Korasick, D.A., Enders, T.A., Strader, L.C., 2013. Auxin biosynthesis and storage forms. Journal of Experimental Botany 64, 2541-55. doi:10.1093/jxb/ert080

Kose, C., Erdal, S., Kaya, O., Atici, O., 2011. Comparative evaluation of oxidative enzyme activities during adventitious rooting in the cuttings of grapevine rootstocks. Journal of the Science of Food and Agriculture 91, $738-741$.

Kowalczyk, M., Sandberg, G., 2001. Quantitative analysis of indole-3-acetic acid metabolites in Arabidopsis. Plant Physiology 127, 1845-1853.

Krisantini, S., Johnston, M., Williams, R.R., Beveridge, C., 2006. Adventitious root formation in Grevillea (Proteaceae), an Australian native species. Scientia Horticulturae 107, 171-175.

Kurd, A.A., Khan, S., Shah, B.H., Khetran, M.A., 2010. Effect of indole butyric acid (IBA) on rooting of olive stem cuttings. Pakistan Journal of Agricultural Research 23, 193-195.

Lee, M.S., Do, J.O., Park, M.S., Jung, S., Lee, K.H., Bae, K.S., Park, S.J., Kim, S.B., 2006. Dominance of Lysobacter sp. in the rhizosphere of two coastal sand dune plant species, Calystegia soldanella and Elymus mollis. Antonie van Leeuwenhoek 90, 19-27.

Legué, V., Rigal, A., Bhalerao, R.P., 2014. Adventitious root formation in tree species: involvement of transcription factors. Physiologia Plantarum 151, 192-198.

León, P., Sheen, J., 2003. Sugar and hormone connections. Trends in Plant Science 8, 110-116.

Leva, A., Petruccelli, R., Bartolini, G., 1994. Mannitol "in vitro" culture of Olea europaea L. (cv. Maurino). Acta Horticulturae 356, 43-46. doi:10.17660/ActaHortic.1994.356.7

Li, M., Huang, Z., 2002. Relationship between the changes of activities and isoenzymes of polyphenol oxidase and the rooting of eucalyptus cuttings after treatment with naphthylacetic acid. Journal of South China Agricultural University $23,45-48$.

Li, M., Huang, Z., Lin, S., Tan, S., Mo, X., Lin, H., Long, T., 2000. Comparative study on the activity and isoenzymes of peroxidase in difficult-and easy-to-root Eucalyptus species. Journal of South China Agricultural University 21, $56-59$.

Li, M., Leung, D.W., 2000. Starch accumulation is associated with adventitious root formation in hypocotyl cuttings of Pinus radiata. Journal of Plant Growth Regulation 19, 423-428.

Li, S.-W., Xue, L., Xu, S., Feng, H., An, L., 2009a. Mediators, genes and signaling in adventitious rooting. The Botanical Review 75, 230-247.

Li, S.-W., Xue, L., Xu, S., Feng, H., An, L., 2009b. Hydrogen peroxide acts as a signal molecule in the adventitious root formation of mung bean seedlings. Environmental and Experimental Botany 65, 63-71.

Li, S.-W., Xue, L., Xu, S., Feng, H., An, L., 2009c. IBA-induced changes in antioxidant enzymes during adventitious rooting in mung bean seedlings: The role of $\mathrm{H} 2 \mathrm{O} 2$. Environmental and Experimental Botany 66, 442-450. 
Linderman, R.G., Davis, E.A., 2001. Comparative response of selected grapevine rootstocks and cultivars to inoculation with different mycorrhizal fungi. American Journal of Enology and Viticulture 52, 8-11.

Liu, Z.-H., Hsiao, I.-C., Pan, Y.-W., 1996. Effect of naphthaleneacetic acid on endogenous indole-3-acetic acid, peroxidase and auxin oxidase in hypocotyl cuttings of soybean during root formation. Botanical Bulletin of Academia Sinica 37.

Ljung, K., 2013. Auxin metabolism and homeostasis during plant development. Development 140, 943-950.

Ljung, K., Bhalerao, R.P., Sandberg, G., 2001. Sites and homeostatic control of auxin biosynthesis in Arabidopsis during vegetative growth. The Plant Journal 28, 465-474.

Ljung, K., Hull, A.K., Celenza, J., Yamada, M., Estelle, M., Normanly, J., Sandberg, G., 2005. Sites and regulation of auxin biosynthesis in Arabidopsis roots. Plant Cell 17, 1090-104.

Ljung, K., Hull, A.K., Kowalczyk, M., Marchant, A., Celenza, J., Cohen, J.D., Sandberg, G., 2002. Biosynthesis, conjugation, catabolism and homeostasis of indole-3-acetic acid in Arabidopsis thaliana, in: Auxin Molecular Biology. Springer, pp. 249-272.

Ljung, K., Nemhauser, J.L., Perata, P., 2015. New mechanistic links between sugar and hormone signalling networks. Current Opinion in Plant Biology 25, 130-137.

Loach, K., Whalley, D., 1978. Water and carbohydrate relationships during the rooting of cuttings. Acta Horticulturae 79, 161-168. doi:10.17660/ActaHortic.1978.79.18

Lopez-Huertas, E., Del Rio, L.A., 2014. Characterization of antioxidant enzymes and peroxisomes of olive (Olea europaea L.) fruits. Journal of Plant Physiology 171, 1463-1471.

Ludwig-Müller, J., 2000. Indole-3-butyric acid in plant growth and development. Plant Growth Regulation 32, 219230.

Ludwig-Müller, J., 2003. Peroxidase isoenzymes as markers for the rooting ability of easy-to-root and difficult-to-root Grevillea species and cultivars of Protea obstusifolia (Proteaceae). In Vitro Cellular \& Developmental BiologyPlant 39, 377-383.

Ludwig-Müller, J., 2011. Auxin conjugates: their role for plant development and in the evolution of land plants. Journal of Experimental Botany 62, 1757-1773.

Ludwig-Müller, J., Epstein, E., 1991. Occurrence and in vivo biosynthesis of indole-3-butyric acid in corn (Zea mays L.). Plant Physiology 97, 765-770.

Ludwig-Müller, J., Vertocnik, A., Town, C.D., 2005. Analysis of indole-3-butyric acid-induced adventitious root formation on Arabidopsis stem segments. Journal of Experimental Botany 56, 2095-2105.

Macedo, E., Vieira, C., Carrizo, D., Porfirio, S., Hegewald, H., Arnholdt-Schmitt, B., Calado, M., Peixe, A., 2013. Adventitious root formation in olive (Olea europaea L.) microshoots: anatomical evaluation and associated biochemical changes in peroxidase and polyphenol oxidase activities. Journal of Horticultural Science \& Biotechnology 88, 53-59.

Macedo, E.S., Cardoso, H.G., Hernández, A., Peixe, A.A., Polidoros, A., Ferreira, A., Cordeiro, A., Arnholdt-Schmitt, B., 2009. Physiologic responses and gene diversity indicate olive alternative oxidase as a potential source for markers involved in efficient adventitious root induction. Physiologia Plantarum 137, 532-552.

Macedo, E.S., Sircar, D., Cardoso, H., Peixe, A., Arnholdt-Schmitt, B., 2012. Involvement of alternative oxidase $(\mathrm{AOX})$ in adventitious rooting of Olea europaea L. microshoots is linked to adaptive phenylpropanoid and lignin metabolism. Plant Cell Reports 1-10.

Mancuso, S., 1998. Seasonal dynamics of electrical impedance parameters in shoots and leaves related to rooting ability of olive (Olea europea) cuttings. Tree Physiology 19, 95-101.

Marschner, H., 1995. Mineral nutrition of higher plants, 2nd ed. Academic Press, San Diego, USA.

Martin-Tanguy, J., 2001. Metabolism and function of polyamines in plants: recent development (new approaches). Plant Growth Regulation 34, 135-148. 
Martin-Tanguy, J., Carré, M., 1993. Polyamines in grapevine microcuttings cultivated in vitro. Effects of amines and inhibitors of polyamine biosynthesis on polyamine levels and microcutting growth and development. Plant Growth Regulation 13, 269-280.

Mato, M., Rua, M., Ferro, E., 1988. Changes in levels of peroxidases and phenolics during root formation in Vitis cultured in vitro. Physiologia Plantarum 72, 84-88.

Mato, M., Vieitez, A., 1986. Changes in auxin protectors and IAA oxidases during the rooting of chestnut shoots in vitro. Physiologia Plantarum 66, 491-494.

Matsuda, F., Miyazawa, H., Wakasa, K., Miyagawa, H., 2005. Quantification of indole-3-acetic acid and amino acid conjugates in rice by liquid chromatography-electrospray ionization-tandem mass spectrometry. Bioscience, Biotechnology, and Biochemistry 69, 778-783.

Mayer, A.M., 2006. Polyphenol oxidases in plants and fungi: Going places? A review. Phytochemistry 67, 2318-2331.

Mechri, B., Attia, F., Tekaya, M., Cheheb, H., Hammami, M., 2014. Colonization of olive trees (Olea europaea L.) with the arbuscular mycorrhizal fungus Glomus sp. modified the glycolipids biosynthesis and resulted in accumulation of unsaturated fatty acids. Journal of Plant Physiology 171, 1217-1220.

Meddad-Hamza, A., Beddiar, A., Gollotte, A., Lemoine, M., Kuszala, C., Gianinazzi, S., 2010. Arbuscular mycorrhizal fungi improve the growth of olive trees and their resistance to transplantation stress. African Journal of Biotechnology 9.

Mekahlia, M.N., Beddiar, A., Chenchouni, H., others, 2013. Mycorrhizal dependency in the olive tree (Olea europaea) across a xeric climatic gradient. Advances in Environmental Biology 7, 2166-2174.

Mencuccini, M., 2003. Effect of medium darkening on in vitro rooting capability and rooting seasonality of olive (Olea europaea L.) cultivars. Scientia Horticulturae 97, 129-139.

Merckelbach, C., Buchala, A., Meier, H., 1991. Adventitious rooting in cuttings of Populus tremula: metabolism of IAA and IBA, in: Proceedings of the 14th International Conference on Plant Growth Substances. Amsterdam, The Netherlands, p. 21.

Molnar, J., LaCroix, L., 1972. Studies of the rooting of cuttings of Hydrangea macrophylla: enzyme changes. Canadian Journal of Botany 50, 315-322.

Montero-Calasanz, M.C., Göker, M., Rohde, M., Spröer, C., Schumann, P., Busse, H.-J., Schmid, M., Klenk, H.-P., Tindall, B.J., Camacho, M., 2014. Chryseobacterium oleae sp. nov., an efficient plant growth promoting bacterium in the rooting induction of olive tree (Olea europaea L.) cuttings and emended descriptions of the genus Chryseobacterium, C. daecheongense, C. gambrini, C. gleum, C. joostei, C. jejuense, C. luteum, C. shigense, C. taiwanense, C. ureilyticum and C. vrystaatense. Systematic and Applied Microbiology 37, 342-350.

Montero-Calasanz, M.C., Santamaría, C., Albareda, M., Daza, A., Duan, J., 2013. Alternative rooting induction of semi-hardwood olive cuttings by several auxin-producing bacteria for organic agriculture systems. Spanish Journal of Agricultural Research 146-154.

Morini, S., Loreti, F., Sciutti, R., others, 1990. Effect of light quality on rooting of "Leccino"olive cuttings. Acta Horticulturae 286, 73-76.

Mousa, A.-A.K., 2003. Rooting Response of "Nabali" and "Improved Nabali" Olive Cuttings to Indole Butyric Acid Concentration and Collection Season. Pakistan Journal of Biological Sciences 6, 2040-2043.

Muday, G.K., Rahman, A., Binder, B.M., 2012. Auxin and ethylene: collaborators or competitors? Trends in Plant Science 17, 181-195. doi:10.1016/j.tplants.2012.02.001

Muraro, D., Byrne, H., King, J., Bennett, M., 2013. The role of auxin and cytokinin signalling in specifying the root architecture of Arabidopsis thaliana. Journal of Theoretical Biology 71-86.

Nag, S., Paul, A., Choudhuri, M., 2013. Changes in peroxidase activity during adventitious root formation at the base of mung bean cuttings. International Journal of Scientific \& Technology Research 2, 171-177.

Nag, S., Saha, K., Choudhuri, M., 2001. Role of auxin and polyamines in adventitious root formation in relation to changes in compounds involved in rooting. Journal of Plant Growth Regulation 20, 182-194. 
Naija, S., Elloumi, N., Ammar, S., Kevers, C., Dommes, J., 2009. Involvement of polyamines in the adventitious rooting of micropropagated shoots of the apple rootstock MM106. In Vitro Cellular \& Developmental Biology-Plant 45, 83-91.

Naija, S., Elloumi, N., Jbir, N., Ammar, S., Kevers, C., 2008. Anatomical and biochemical changes during adventitious rooting of apple rootstocks MM 106 cultured in vitro. Comptes Rendus Biologies 331, 518-525.

Negi, S., Sukumar, P., Liu, X., Cohen, J.D., Muday, G.K., 2010. Genetic dissection of the role of ethylene in regulating auxin-dependent lateral and adventitious root formation in tomato. The Plant Journal 61, 3-15.

Neves, C., Santos, H., Vilas-Boas, L., Amâncio, S., 2002. Involvement of free and conjugated polyamines and free amino acids in the adventitious rooting of micropropagated cork oak and grapevine shoots. Plant Physiology and Biochemistry 40, 1071-1080. doi:10.1016/S0981-9428(02)01472-9

Niemi, K., Scagel, C., Häggman, H., 2004. Application of ectomycorrhizal fungi in vegetative propagation of conifers. Plant Cell, Tissue and Organ Culture 78, 83-91.

Nordström, A.-C., Eliasson, L., 1984. Regulation of root formation by auxin-ethylene interaction in pea stem cuttings. Physiologia Plantarum 61, 298-302.

Nordström, A.-C., Jacobs, F.A., Eliasson, L., 1991. Effect of exogenous indole-3-acetic acid and indole-3-butyric acid on internal levels of the respective auxins and their conjugation with aspartic acid during adventitious root formation in pea cuttings. Plant Physiology 96, 856-861.

Normanly, J., 2010. Approaching cellular and molecular resolution of auxin biosynthesis and metabolism. Cold Spring Harbor Perspectives in Biology 2, a001594.

Normanly, J., Slovin, J.P., Cohen, J.D., 2010. Auxin biosynthesis and metabolism, in: Davies P. (Ed.), Springer Netherlands, pp. 36-62. doi:10.1007/978-1-4020-2686-7_3

Ortega-García, F., Blanco, S., Peinado, M.Á., Peragón, J., 2008. Polyphenol oxidase and its relationship with oleuropein concentration in fruits and leaves of olive (Olea europaea) cv. "Picual" trees during fruit ripening. Tree Physiology 28, 45-54.

Ortega-García, F., Peragón, J., 2009. Phenylalanine ammonia-lyase, polyphenol oxidase, and phenol concentration in fruits of Olea europaea L. cv. Picual, Verdial, Arbequina, and Frantoio during ripening. Journal of Agricultural and Food Chemistry 57, 10331-10340.

Overvoorde, P., Fukaki, H., Beeckman, T., 2010. Auxin control of root development. Cold Spring Harbor Perspectives in Biology 2, a001537. doi: 10.1101/cshperspect.a001537

Özkaya, M., Çelik, M., 1994. The effect of rooting environment and combination of auxin polyamine on the rooting ability of Turkish olive cultivars Gemlik and Domat. Acta Horticulturae 356, 31-34.

Özkaya, M., Çelik, M., 1999. The effects of various treatments on endogenous carbohydrate content of cuttings in easyto-root and hard-to-root olive cultivars. Acta Horticulturae 474, 51-54. doi:10.17660/ActaHortic.1999.474.5

Pacurar, D.I., Perrone, I., Bellini, C., 2014. Auxin is a central player in the hormone cross-talks that control adventitious rooting. Physiologia Plantarum 151, 83-96.

Pan, M., Van Staden, J., 1998. The use of charcoal in in vitro culture-A review. Plant Growth Regulation 26, 155-163.

Pan, R., Gui, H., 1997. Physiological basis of the synergistic effects of IBA and triadimefon on rooting of mung bean hypocotyls. Plant Growth Regulation 22, 7-11.

Pan, R., Wang, J., Tian, X., 2002. Influence of ethylene on adventitious root formation in mung bean hypocotyl cuttings. Plant Growth Regulation 36, 135-139.

Park, J.-B., Lee, K.-B., Lee, S., 2002. Histological study of callus formation and root regeneration from mung bean (Vigna radiata W.). Journal of Plant Biology 45, 170-176.

Passardi, F., Cosio, C., Penel, C., Dunand, C., 2005. Peroxidases have more functions than a Swiss army knife. Plant Cell Reports 24, 255-265.

Pastur, G.M., Zappacosta, D., Arena, M., Curvetto, N., 2001. Changes in isoperoxidase patterns during the in vitro rooting of Nothofagus antarctica. Bulgarian Journal of Plant Physiology 27, 43-53. 
Peck, S.C., Kende, H., 1995. Sequential induction of the ethylene biosynthetic enzymes by indole-3-acetic acid in etiolated peas. Plant Molecular Biology 28, 293-301.

Peer, W.A., Blakeslee, J.J., Yang, H., Murphy, A.S., 2011. Seven things we think we know about auxin transport. Molecular Plant 4, 487-504.

Peer, W.A., Murphy, A.S., 2007. Flavonoids and auxin transport: modulators or regulators? Trends in Plant Science $12,556-63$.

Peixe, A., Raposo, A., Lourenço, R., Cardoso, H., Macedo, E., 2007a. Coconut water and BAP successfully replaced zeatin in olive (Olea europaea L.) micropropagation. Scientia Horticulturae 113, 1-7.

Peixe, A., Serras, M., Campos, C., Zavattieri, M., Dias, M.A., 2007b. Estudo histológico sobre a formação de raizes adventicias em estacas caulinares de oliveira (Olea europaea L.). Revista de Ciências Agrárias 30, 476-482.

Pěnčík, A., Rolčík, J., Novák, O., Magnus, V., Barták, P., Buchtík, R., Salopek-Sondi, B., Strnad, M., 2009. Isolation of novel indole-3-acetic acid conjugates by immunoaffinity extraction. Talanta 80, 651-655.

Petricka, J.J., Winter, C.M., Benfey, P.N., 2012. Control of Arabidopsis root development. Annual Review of Plant Biology 63, 563.

Piedra, A.P., Martin, M.L.S., Corral, J.M.A., Reyes, C.P., Toledano, L.A., Soriano, A.P., 2003. Micorrización de estaquillas de olivo propagadas bajo nebulización. Agricultura: Revista Agropecuaria 784-787.

Pijut, P.M., Woeste, K.E., Michler, C.H., 2011. Promotion of Adventitious Root Formation of Difficult-to-Root Hardwood Tree Species, in: Janick J. (Ed.), Horticultural Reviews. Wiley-Blackwell, pp. 213-251.

Pio, R., Bastos, D.C., Berti, A.J., Scarpare Filho, J.A., Mourão Filho, F.A.A., Entelmann, F.A., Alves, A.S.R., Neto, J.E.B., 2005. Enraizamento de diferentes tipos de estacas de oliveira (Olea europaea L.) utilizando ácido indolbutirico. Ciência e Agrotecnologia 29, 562-567.

Pop, T.I., Pamfil, D., Bellini, C., 2011. Auxin control in the formation of adventitious roots. Notulae Botanicae Horti Agrobotanici Cluj-Napoca 39, 307-316.

Porlingis, I., Therios, I., 1976. Rooting response of juvenile and adult leafy olive cuttings to various factors. Journal of Horticultural Science.

Porras-Soriano, A., Soriano-Martin, M.L., Porras-Piedra, A., Azcón, R., 2009. Arbuscular mycorrhizal fungi increased growth, nutrient uptake and tolerance to salinity in olive trees under nursery conditions. Journal of Plant Physiology $166,1350-1359$.

Preece, J.E., 2003. A century of progress with vegetative plant propagation. HortScience 38(5), 1015-1025.

Qaddoury, A., Amssa, M., 2003. Endogenous phenolic contents, peroxidase and polyphenoloxidase activities in date palm (Phoenix dactylifera L.) offshoots related to rooting ability. Acta Physiologiae Plantarum 25, 417-421.

Qrunfleh, M., Rushdi, Y., Musmar, T., Rushdi, L., 1994. Root formation in cuttings of the "Nabali" olives with uniconazole and indolebutyric acid. Dirasat: Agricultural Sciences 21, 71-79.

Quoirin, M., Boxus, P., Gaspar, T., 1974. Root initiation and isoperoxidases of stem tip cuttings from mature Prunus plants. Physiologie Végétale.

Rademacher, W., Jung, J., Graebe, J., Schwenen, L., 1984. On the mode of action of tetcyclacis and triazole growth retardants. Monograph-British Plant Growth Regulation Group 11, 1-11.

Rademacher, W., 2015. Plant growth regulators: backgrounds and uses in plant production. Journal of Plant Growth and Regulation 34, 845-872.

Ragonezi, C., Klimaszewska, K., Castro, M.R., Lima, M., de Oliveira, P., Zavattieri, M.A., 2010. Adventitious rooting of conifers: influence of physical and chemical factors. Trees 24, 975-992.

Rahman, A., Amakawa, T., Goto, N., Tsurumi, S., 2001. Auxin is a positive regulator for ethylene-mediated response in the growth of Arabidopsis roots. Plant and Cell Physiology 42, 301-307. doi:10.1093/pcp/pce035

Ranjit, M., Kester, D., Polito, V., 1988. Micropropagation of cherry rootstocks. III. Correlations between anatomical and physiological parameters and root initiation. Journal of the American Society for Horticultural Science. 
Rigal, A., Yordanov, Y.S., Perrone, I., Karlberg, A., Tisserant, E., Bellini, C., Busov, V.B., Martin, F., Kohler, A., Bhalerao, R., others, 2012. The AINTEGUMENTA LIKE1 homeotic transcription factor PtAIL1 controls the formation of adventitious root primordia in poplar. Plant Physiology 160, 1996-2006.

Riov, J., Yang, S., 1989. Ethylene and auxin-ethylene interaction in adventitious root formation in mung bean (Vigna radiata) cuttings. Journal of Plant Growth Regulation 8, 131-141.

Rival, A., Bernard, F., Mathieu, Y., 1997. Changes in peroxidase activity during in vitro rooting of oil palm (Elaeis guineensis Jacq.). Scientia Horticulturae 71, 103-112.

Robards, K., Prenzler, P.D., Tucker, G., Swatsitang, P., Glover, W., 1999. Phenolic compounds and their role in oxidative processes in fruits. Food Chemistry 66, 401-436.

Robles, L., Stepanova, A., Alonso, J., 2013. Molecular mechanisms of ethylene-auxin interaction. Molecular Plant 6, 1734-1737.

Roldán-Fajardo, B., Barea, J., 1985. Mycorrhizal dependency in the olive tree (Olea europaea L.), in: GianinazziPearson, V. and Gianinazzi, S. (Ed.), Physiological and Genetical Aspects of Mycorrhizal. INRA, Paris, pp. 323326.

Rout, G., Samantaray, S., Das, P., 2000. In vitro rooting of Psoralea corylifolia Linn: Peroxidase activity as a marker. Plant Growth Regulation 30, 215-219.

Rout, G., Samantaray, S., Rout, M., Das, P., 1996. Metabolic changes during rooting in stem cuttings of Casuarina equisetifolia L.: effects of auxin, the sex and the type of cutting on rooting. Plant Growth Regulation 19, 35-43.

Rout, G.R., 2006. Effect of auxins on adventitious root development from single node cuttings of Camellia sinensis (L.) Kuntze and associated biochemical changes. Plant Growth Regulation 48, 111-117.

Ruedell, C.M., de Almeida, M.R., Schwambach, J., Posenato, C.F., Fett-Neto, A.G., 2013. Pre and post-severance effects of light quality on carbohydrate dynamics and microcutting adventitious rooting of two Eucalyptus species of contrasting recalcitrance. Plant Growth Regulation 69, 235-245.

Rugini, E., 1992. Involvement of Polyamides in Auxin and Agrobacterium rhizogenes-induced Rooting of Fruit Trees in Vitro. Journal of the American Society for Horticultural Science 117, 532-536.

Rugini, E., Bazzoffia, A., Jacoboni, A., 1988. A simple in vitro method to avoid the initial dark period and to increase rooting in fruit trees. Acta Horticulturae 227, 438-440.

Rugini, E., Di Francesco, G., Muganu, M., Astolfi, S., Caricato, G., 1997. The effects of polyamines and hydrogen peroxide on root formation in olive and the role of polyamines as an early marker for rooting ability, in: Altman, A. and Waisel, Y. (Ed.), Biology of Root Formation and Development. Plenum Press, New York, USA, pp. 65-73.

Rugini, E., Fedeli, E., 1990. Olive (Olea europaea L.) as an oilseed crop, in: Bajaj, Y.P.S. (Ed.), Legumes and Oilseed Crops I, Biotechnology in Agriculture and Forestry. Springer-Verlag, Berlin Heidelberg, pp. 593-641. doi:10.1007/978-3-642-74448-8_29

Rugini, E., Jacoboni, A., Luppino, M., 1993. Role of basal shoot darkening and exogenous putrescine treatments on in vitro rooting and on endogenous polyamine changes in difficult-to-root woody species. Scientia Horticulturae 53, $63-72$.

Rugini, E., Luppino, M., Grego, S., de Agazio, M., 1992. Endogenous polyamine and root morphogenesis variations under different treatments in cuttings and in in vitro explants of olive. Acta Hoticulturae 300, 225-232. doi:10.17660/ActaHortic.1992.300.31

Rugini, E., Pannelli, G., 1993. Olive (Olea europaea L.) biotechnology for short term genetic improvement. AgroFood-Industry Hi-Tech 4, 3-5.

Rugini, E., Politi, V., Bignami, C., De Agazio, M., Grego, S., 1990. Effect of polyamine treatments on rooting cuttings of three olive cultivars. Acta Horticulturae 286, 97-100.

Rugini, E., Wang, X., 1986. Effect of Polyamines, 5-azacytidine and Growth Regulators on rooting in vitro of fruit trees, treated and untreated with Agrobacterium rhizogenes, in: Proceedings of the International Congress of Plant Tissue and Cell Culture. Minnesota. Minneapolis, MN, USA, p. 374. 
Růzicka, K., Ljung, K., Vanneste, S., Podhorská, R., Beeckman, T., Friml, J., Benková, E., 2007. Ethylene regulates root growth through effects on auxin biosynthesis and transport-dependent auxin distribution. Plant Cell 19, 2197212. doi:10.1105/tpc. 107.052126

Sagee, O., Raviv, M., Medina, S., Becker, D., Cosse, A., 1992. Involvement of rooting factors and free IAA in the rootability of citrus species stem cuttings. Scientia Horticulturae 51, 187-195.

Sairanen, I., Novák, O., Pěnčík, A., Ikeda, Y., Jones, B., Sandberg, G., Ljung, K., 2012. Soluble carbohydrates regulate auxin biosynthesis via PIF proteins in Arabidopsis. Plant Cell 24, 4907-4916.

Salama, M., Zahran, M., Hassan, M., 1987. Comparing the rooting ability of some olive cultivars propagated by leafy cuttings under mist. Annals of Agricultural Science (Egypt).

Samartin, A., Vieitez, A., Vieitez, E., 1986. Rooting of tissue cultured camellias. Journal of Horticultural Science 61, $113-120$.

San-José, M., Vidal, N., Ballester, A., 1992. Anatomical and biochemical changes during root formation in oak and apple shoots cultured in vitro. Agronomie 12, 767-774.

Saraiva, J.A., Nunes, C.S., Coimbra, M.A., 2007. Purification and characterization of olive (Olea europaea L.) peroxidase-Evidence for the occurrence of a pectin binding peroxidase. Food Chemistry 101, 1571-1579.

Satisha, J., Raveendran, P., Rokade, N., 2008. Changes in polyphenol oxidase activity during rooting of hardwood cuttings in three grape rootstocks under Indian conditions. South African Society for Enology \& Viticulture 29, 94 97.

Schwambach, J., Fadanelli, C., Fett-Neto, A.G., 2005. Mineral nutrition and adventitious rooting in microcuttings of Eucalyptus globulus. Tree Physiology 25, 487-494.

Sciancalepore, V., Longone, V., 1984. Polyphenol oxidase activity and browning in green olives. Journal of Agricultural and Food Chemistry 32, 320-321.

Sebastiani, L., Tognetti, R., 2004. Growing season and hydrogen peroxide effects on root induction and development in Olea europaea L. (cvs "Frantoio"and "Gentile di Larino") cuttings. Scientia Horticulturae 100, 75-82.

Sebastiani, L., Tognetti, R., Di Paolo, P., Vitagliano, C., 2002. Hydrogen peroxide and indole-3-butyric acid effects on root induction and development in cuttings of Olea europaea L.(cv. Frantoio and Gentile di Larino). Advances in Horticultural Science 16, 7-12.

Segovia-Bravo, K.A., Jarén-Galán, M., García-García, P., Garrido-Fernández, A., 2007. Characterization of polyphenol oxidase from the Manzanilla cultivar (Olea europaea pomiformis) and prevention of browning reactions in bruised olive fruits. Journal of Agricultural and Food Chemistry 55, 6515-6520.

Serra, C., Antunes, R., Hegewald, H., Costa, C., Pinto, A., Peixe, A., 2007. Quantificação dos niveis endógenos de auxinas e da actividade enzimática das polifenoloxidases em oliveira (Olea europaea L.). Revista de Ciências Agrárias 30, 491-499.

Serrano, J., Serrano, M., Amaral, E., 2002. Effect of different hormone treatments on rooting of Olea europaea cv. Galega vulgar cuttings. Acta Horticulturae 586, 875-877.

Sghir, S., Chatelet, P., Ouazzani, N., Dosba, F., Belkoura, I., 2005. Micropropagation of eight Moroccan and French olive cultivars. HortScience 40, 193-196.

Shomer, I., Ben-Shalom, N., Harel, E., Mayer, A., 1979. The intracellular location of catechol oxidase in the olive fruit. Annals of Botany 44, 261-263.

Sircar, P., Chatterjee, S., 1973. Physiological and biochemical control of meristemization and adventitious root formation in Vigna hypocotyl cuttings. Plant Propagator 19, 1.

Sitbon, F., Ostin, A., Sundberg, B., Olsson, O., Sandberg, G., 1993. Conjugation of Indole-3-Acetic Acid (IAA) in Wild-Type and IAA-Overprodcing Transgenic Tobacco Plants, and Identification of the Main Conjugates by FritFast Atom Bombardment Liquid Chromatography-Mass Spectrometry. Plant Physiology 101, 313-320.

Smith, S.E., Read, D.J., 2010. Mycorrhizal symbiosis. Academic Press. 
Sorin, C., Bussell, J.D., Camus, I., Ljung, K., Kowalczyk, M., Geiss, G., McKhann, H., Garcion, C., Vaucheret, H., Sandberg, G., others, 2005. Auxin and light control of adventitious rooting in Arabidopsis require ARGONAUTE1. Plant Cell 17, 1343-1359.

Sorin, C., Negroni, L., Balliau, T., Corti, H., Jacquemot, M.-P., Davanture, M., Sandberg, G., Zivy, M., Bellini, C., 2006. Proteomic analysis of different mutant genotypes of Arabidopsis led to the identification of 11 proteins correlating with adventitious root development. Plant Physiology 140, 349-364.

Spagna, G., Barbagallo, R.N., Chisari, M., Branca, F., 2005. Characterization of a tomato polyphenol oxidase and its role in browning and lycopene content. Journal of Agricultural and Food Chemistry 53, 2032-2038.

Staswick, P.E., 2009. The tryptophan conjugates of jasmonic and indole-3-acetic acids are endogenous auxin inhibitors. Plant Physiology 150, 1310-1321.

Štefančič, M., Štampar, F., Veberič, R., Osterc, G., 2007. The levels of IAA, IAAsp and some phenolics in cherry rootstock "GiSelA 5" leafy cuttings pretreated with IAA and IBA. Scientia Horticulturae 112, 399-405.

Stepanova, A.N., Hoyt, J.M., Hamilton, A.A., Alonso, J.M., 2005. A link between ethylene and auxin uncovered by the characterization of two root-specific ethylene-insensitive mutants in Arabidopsis. Plant Cell 17, 2230-2242.

Stepanova, A.N., Yun, J., Likhacheva, A.V., Alonso, J.M., 2007. Multilevel interactions between ethylene and auxin in Arabidopsis roots. Plant Cell 19, 2169-85.

Strader, L.C., Bartel, B., 2011. Transport and metabolism of the endogenous auxin precursor indole-3-butyric acid. Molecular Plant 4, 477-486.

Strader, L.C., Wheeler, D.L., Christensen, S.E., Berens, J.C., Cohen, J.D., Rampey, R.A., Bartel, B., 2011. Multiple facets of Arabidopsis seedling development require indole-3-butyric acid-derived auxin. The Plant Cell Online 23, 984-999.

Suárez, M., Lopez-Rivares, E., Lavee, S., Troncoso, A., 1999. Rooting capability of olive cuttings, cv. Gordal: Influence of the presence of leaves and buds. Acta Horticulturae 474, 39-42. doi:10.17660/ActaHortic.1999.474.2

Subramanian, N., Venkatesh, P., Ganguli, S., Sinkar, V.P., 1999. Role of polyphenol oxidase and peroxidase in the generation of black tea theaflavins. Journal of Agricultural and Food Chemistry 47, 2571-2578.

Sukumar, P., 2010. The role of auxin and ethylene in adventitious root formation in Arabidopsis and tomato. PhD thesis. Wake Forest University, Winston-Salem, NC, USA.

Swarup, R., Perry, P., Hagenbeek, D., Van Der Straeten, D., Beemster, G.T.S., Sandberg, G., Bhalerao, R., Ljung, K., Bennett, M.J., 2007. Ethylene upregulates auxin biosynthesis in Arabidopsis seedlings to enhance inhibition of root cell elongation. Plant Cell 19, 2186-96. doi:10.1105/tpc.107.052100

Syros, T., Yupsanis, T., Zafiriadis, H., Economou, A., 2004. Activity and isoforms of peroxidases, lignin and anatomy, during adventitious rooting in cuttings of Ebenus cretica L. Journal of Plant Physiology 161, 69-77.

Szecskó, V., Hrotkó, K., Stefanovits-Bányai, É., 2004. Phenolic Compounds, Bud Dormancy, and Rooting Ability of Plum Hardwood Cuttings. Acta Horticulturae 658, 679-687.

Takahashi, T., Kakehi, J.-I., 2010. Polyamines: ubiquitous polycations with unique roles in growth and stress responses. Annals of Botany 105, 1-6.

Talaie, A., Ghassemi, M., 1996. Study of the Effect of Different Media Beds, Time, and Wounding Factors on the Rooting of Semi-hard Cuttings of Olive [Olea europaea (Roghani \& Zard Zeitoun CV)] under Mist Conditions. HortScience 31, 635-635.

Talaie, A., Malakroodi, M.R., 1995. Rooting Systems of Semi-hardwood Olive Cuttings of Three Selected Varieties of Manzanilla, Sevillana, and Clonavis. HortScience 30, 843-843.

Tartoura, K., Da Rocha, A., Youssef, S., 2004. Synergistic interaction between coumarin 1, 2-benzopyrone and indole3-butyric acid in stimulating adventitious root formation in Vigna radiata (L.) Wilczek cuttings: I. Endogenous free and conjugated IAA and basic isoperoxidases. Plant Growth Regulation 42, 253-262.

Teale, W.D., Paponov, I.A., Palme, K., 2006. Auxin in action: signalling, transport and the control of plant growth and development. Nature Reviews Molecular Cell Biology 7, 847-859.

Therios, I.N., 2009. Olives. CABI. 
Thipyapong, P., Hunt, M.D., Steffens, J.C., 1995. Systemic wound induction of potato (Solanum tuberosum) polyphenol oxidase. Phytochemistry 40, 673-676.

Tiburcio, A.F., Altabella, T., Borrell, A., Masgrau, C., 1997. Polyamine metabolism and its regulation. Physiologia Plantarum 100, 664-674.

Tiburcio, A.F., Gendy, C.A., Van, K.T.T., 1989. Morphogenesis in tobacco subepidermal cells: putrescine as marker of root differentiation. Plant Cell, Tissue and Organ Culture 19, 43-54.

Tiburcio, A.F., Kaur-Sawhney, R., Galston, A.W., 1987. Effect of polyamine biosynthetic inhibitors on alkaloids and organogenesis in tobacco callus cultures. Plant Cell, Tissue and Organ Culture 9, 111-120.

Tonon, G., Kevers, C., Gaspar, T., 2001. Changes in polyamines, auxins and peroxidase activity during in vitro rooting of Fraxinus angustifolia shoots: an auxin-independent rooting model. Tree Physiology 21, 655-663.

Tromas, A., Paponov, I., Perrot-Rechenmann, C., 2010. AUXIN BINDING PROTEIN 1: functional and evolutionary aspects. Trends in Plant Science 15, 436-446.

Tsai, C.-J., 2013. Next-generation sequencing for next-generation breeding, and more. New Phytologist 198, 635-637.

Tzika, E.D., Sotiroudis, T.G., Papadimitriou, V., Xenakis, A., 2009. Partial purification and characterization of peroxidase from olives (Olea europaea cv. Koroneiki). European Food Research and Technology 228, 487-495.

Ubeda-Tomás, S., Beemster, G.T., Bennett, M.J., 2012. Hormonal regulation of root growth: integrating local activities into global behaviour. Trends in Plant Science 17, 326-331.

Upadhyaya, A., Davis, T.D., Sankhla, N., 1986. Some biochemical changes associated with paclobutrazol-induced adventitious root formation on bean hypocotyl cuttings. Annals of Botany 57, 309-315.

Usta, S., 1999. The research on rooting ability of olive cuttings (Olea europae L. cv. Domat). Acta Horticulturae 474, 63-66. doi:10.17660/ActaHortic.1999.474.8

Van der Krieken, W.M., Breteler, H., Visser, M.H., Mavridou, D., 1993. The role of the conversion of IBA into IAA on root regeneration in apple: introduction of a test system. Plant Cell Reports 12, 203-206.

Van Hoof, P., Gaspar, T., 1976. Peroxidase and isoperoxidase changes in relation to root initiation of Asparagus cultured in vitro. Scientia Horticulturae 4, 27-31.

Vidoz, M.L., Loreti, E., Mensuali, A., Alpi, A., Perata, P., 2010. Hormonal interplay during adventitious root formation in flooded tomato plants. The Plant Journal 63, 551-562.

Vieitez, A.M., Vieitez, L., Ballester, A., 1981. In vitro chestnut regeneration anatomical and chemical changes during the rooting process, in: Colloq. Int. Sur La Culture in Vitro Des Assences Forestières. IUFRO, Fountainebleau. pp. $149-152$.

Visser, E.J., Cohen, J.D., Barendse, G.W., Blom, C.W., Voesenek, L.A., 1996. An ethylene-mediated increase in sensitivity to auxin induces adventitious root formation in flooded Rumex palustris Sm. Plant Physiology 112, $1687-1692$.

Waliszewski, K.N., Márquez, O., Pardio, V.T., 2009. Quantification and characterisation of polyphenol oxidase from vanilla bean. Food Chemistry 117, 196-203.

Wang, S., Faust, M., 1986. Effect of growth retardants on root formation and polyamine content in apple seedlings. Journal of the American Society for Horticultural Science 111, 912-917.

Wiesman, Z., Riov, J., Epstein, E., 1989. Characterization and rooting ability of indole-3-butyric acid conjugates formed during rooting of mung bean cuttings. Plant Physiology 91, 1080-1084.

Wiesman, Z., Riov, J., Epstein, E., 1989. Paclobutrazol and urea-phosphate increase rooting and survival of peach Maravilha softwood cuttings. HortScience 24, 908-909.

Wilmowicz, E., Frankowski, K., Kesy, J., Glazi'nska, P., Wojciechowski, W., Ku'cko, A., Kopcewicz, J., 2013. The role of PnACO1 in light-and IAA-regulated flower inhibition in Pharbitis nil. Acta Physiologiae Plantarum 35, 801810. 
Woodward, A.W., Bartel, B., 2005. Auxin: regulation, action, and interaction. Annals of Botany 95, 707-735.

Xiaoman, J., Jianping, Z., Kehua, B., 1998. Studies on peroxidase activity and isoperoxidase in Cucurbita moschata during rooting induction. Acta Botanica Boreali-Occidentalia Sinica 3.

Yilmaz, H., Taskin, T., Otludil, B., 2003. Polyphenol oxidase activity during rooting in cuttings of grape (Vitis vinifera L.) varieties. Turkish Journal of Botany 27, 495-498.

Yoo, Y.K., Kim, K.S., 1996. Seasonal variation in rooting ability, plant hormones, carbohydrate, nitrogen, starch, and soluble sugar contents in cuttings of white forsythia (Abeliophyllum distichum Nakai). Journal of the Korean Society for Horticultural Science 37, 554-560.

Yun, H.R., Joo, S.-H., Park, C.H., Kim, S.-K., Chang, S.C., Kim, S.Y., 2009. Effects of brassinolide and IAA on ethylene production and elongation in maize primary roots. Journal of Plant Biology 52, 268-274

Zacchini, M., De Agazio, M., 2004. Micropropagation of a local olive cultivar for germplasm preservation. Biologia Plantarum 48, 589-592.

Zažímalová, E., Murphy, A.S., Yang, H., Hoyerová, K., Hošek, P., 2010. Auxin transporters — why so many? Cold Spring Harbor perspectives in biology 2.

Zhao, Y., 2010. Auxin biosynthesis and its role in plant development. Annual Review of Plant Biology 61, 49.

Zhi-Guo, E., Ge, L., Wang, L., 2012. Molecular mechanism of adventitious root formation in rice. Plant Growth Regulation 68, 325-331.

Zhou, J., Wu, H., Collet, G., 1992. Histological study of initiation and development in vitro of adventitious roots in minicuttings of apple rootstocks of M 26 and EMLA 9. Physiologia Plantarum 84, 433-440.

Zolman, B.K., Martinez, N., Millius, A., Adham, A.R., Bartel, B., 2008. Identification and characterization of Arabidopsis indole-3-butyric acid response mutants defective in novel peroxisomal enzymes. Genetics 180, 237251.

Zolman, B.K., Nyberg, M., Bartel, B., 2007. IBR3, a novel peroxisomal acyl-CoA dehydrogenase-like protein required for indole-3-butyric acid response. Plant Molecular Biology 64, 59-72.

Zolman, B.K., Yoder, A., Bartel, B., 2000. Genetic analysis of indole-3-butyric acid responses in Arabidopsis thaliana reveals four mutant classes. Genetics 156, 1323-1337. 